Discussion Paper No. 01-38

\title{
Labour Reallocation During Transition: The Case of Poland
}

Una-Louise Bell

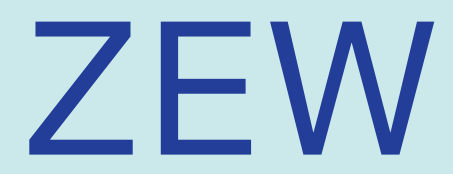

Zentrum für Europäische Wirtschaftsforschung GmbH

Centre for European Economic Research 

Discussion Paper No. 01-38

\title{
Labour Reallocation During Transition: The Case of Poland
}

\author{
Una-Louise Bell
}

Download this and other ZEW Discussion Papers at our ftp server:

ftp://ftp.zew.de/pub/zew-docs/dp/dp0138.pdf

Die Discussion Papers dienen einer möglichst schnellen Verbreitung von neueren Forschungsarbeiten des ZEW. Die Beiträge liegen in alleiniger Verantwortung der Autoren und stellen nicht notwendigerweise die Meinung des ZEW dar.

Discussion Papers are intended to make results of ZEW research promptly available to other economists in order to encourage discussion and suggestions for revisions. The authors are solely responsible for the contents which do not necessarily represent the opinion of the ZEW. 



\title{
LABOUR REALLOCATION DURING TRANSITION: THE CASE OF POLAND
}

\author{
Una-Louise Bell \\ Zentrum für Europäische Wirtschaftsforschung, \\ L7, $1 \cdot$ D-68161 Mannheim.
}

\begin{abstract}
This paper analyses the reallocation of labour during the transition period, which is argued not only to ease the transition from a planned to market orientated economy, but also to be fundamental to the successful integration of Poland into the European Union. Labour force survey data is used to gauge the overall level of reallocation during the period 1994-1998, a period in which the transition process is considered to be well and truly under way. The results obtained illustrate the inherent immobility prevailing in the Polish labour market during this period and would appear to suggest the presence of relatively significant structural rigidities in the labour market. It is argued that mobility rates of this magnitude are likely to result in considerable strains being placed on the Polish economy when it enters the European Union and could, over the medium term, result in relatively high levels of unemployment. Unless mobility is stimulated, European accession is therefore likely to be a socially costly process. The microeconometric analysis of the determinants of individual mobility presented in the second part of the paper offers a first step to identifying the demographic, economic and social attributes which either aid or inhibit effective labour reallocation. The results obtained highlight a number of important differences in mobility behaviour across age, gender, educational attainment, occupational grouping and labour market experience, which will need to be taken into account in the formulation of active labour market policies to stimulate individual mobility.
\end{abstract}




\section{Non-Technical Summary}

This paper analyses the reallocation of labour during the transition period, which is argued not only to ease the transition from a planned to market orientated economy, but also to be fundamental to the successful integration of Poland into the European Union. Labour force survey data is used to gauge the overall level of reallocation during the period 1994-1998, a period in which the transition process is considered to be well and truly under way. The results obtained illustrate the inherent immobility prevailing in the Polish labour market during this period and would appear to suggest the presence of relatively significant structural rigidities in the labour market. For, despite a number of significant changes in the structure of the Polish labour market during the sample period, aggregate mobility in Poland has remained at a relatively low level. It is argued that mobility rates of this magnitude are likely to result in considerable strains being placed on the Polish economy when it enters the European Union and could, over the medium term, result in relatively high levels of unemployment. Unless mobility is stimulated, European accession is therefore likely to be a socially costly process. Moreover, the relatively constant transition rates obtained throughout the sample period would tend to suggest that Polish aggregate mobility patterns are not significantly affected by prevailing economic conditions. This finding in itself, raises doubts as to the ability of labour to act as an effective adjustment mechanism in the face of adverse shocks once control of Polish monetary policy has been handed over to the European Central Bank.

The microeconometric analysis of the determinants of individual mobility presented in the second part of the paper is a first step to identifying the demographic, economic and social attributes which either aid or inhibit effective labour reallocation. It is argued that disaggregated information of this nature is essential to the formulation of effective active labour policy, since it enables one to identify those individuals who, for example, either: i) experience relatively more difficulty in successfully securing employment; or ii) are more likely to become marginalised from the labour force in the aftermath of the loss of employment and on whom labour market policy might therefore, be more effectively targeted. The results obtained highlight a number of important differences in mobility behaviour across age, gender, educational attainment, occupational grouping and labour market experience. As one might expect, the youth labour market is found be relatively more dynamic than that of other age groups, this is reflected in both lower employment retention rates and higher transition probabilities between employment and both unemployment and out of the labour force. The most "fragile" age group, on the other hand, would appear to be those individuals aged 45 years and over: exits from employment for this age group being dominated by flows out of the labour force. Moreover, these individuals appear to find it relatively more difficult 
to re-integrate themselves back into the labour market than younger age groups. Education is also found to be fundamental, not only to the degree of overall, but also to the very nature of the transition themselves. More educated individuals tending to be relatively more likely to transit either from one job to another or from unemployment to employment and perhaps more importantly, to successfully integrate themselves into the workforce. As observed in other industrialised countries, women tend to exhibit weaker labour force attachment than men, a phenomenon which would appear to have increased somewhat over the sample period. Thus, although, the female employment retention rate is only slightly lower than that of males, once their employment relationship is terminated Polish women find it relatively more difficult to find another job. 


\section{Introduction ${ }^{1}$}

The introduction of a market orientated economy by its very nature, entails a significant degree of reallocation of workers across both jobs, occupation, industries and geographical location. Yet, somewhat surprisingly, existing studies (Steiner \& Kwiatkowski (1995) and Boeri \& Flinn (1999)) illustrate that despite the profound changes which occurred in Poland, labour turnover appears to be considerably lower than that of the other industrialised countries ${ }^{2}$. The Boeri \& Flinn result's indicating that labour turnover tends to be even lower than that of Italy, one of the more sclerotic European labour markets!

Levels of this magnitude are somewhat worrisome, since they suggest that labour reallocation in Poland is not sufficient enough to facilitate structural shifts in labour demand which are known to occur with transition and thus to ease the economy's passage from a centrally planned to a market orientated economy. Labour reallocation is also of fundamental importance to the European Union (EU) accession debate. Of late, Poland, along with a number of other Central European economies, has been exerting increasing pressure on Brussels for early entry to the EU. If negotiations proceed according to the Polish Government's timetable, Poland hopes to be granted membership within the next 2-3 years. Whilst membership to the Union will undoubtedly provide Poland with a number of benefits, admission will not provide an automatic remedy for the entrant's economic ailments. Moreover, in common with the introduction of market forces, entry to the EU will, as the experience of the less developed Southern economies has clearly shown, inevitably result in externally imposed increased impetus for structural change ${ }^{3}$. The effective reallocation of labour, whilst not the only issue of concern, is required to facilitate such structural shifts. Whilst the degree of structural change will inevitably depend on the intensity of the accession process, Poland needs to ensure that its labour force is suitably equipped to cope with the increased demands that accession will inevitably place on it. Failure to do so is, as the Spanish experience clearly illustrates, likely to result in significant increases in unemployment and a further increase in regional imbalances, thereby rendering accession a socially costly process ${ }^{4}$. Of more immediate concern is

\footnotetext{
${ }^{1}$ I am grateful to Leszek Kucharski, Charlotte Lauer, Patrick Puhani, Viktor Steiner and especially Jan Rutkowski for their comments and suggestions. I would also like to thank Laura Correro for excellent research assistance and Margorzata Kalaska for insights into the Polish Labour Force Survey. This research is supported by the European Union. Phare ACE Programme under the project P97-8055-R, entitled "Labour Market Flexibility in the Wake of EU Accession - Poland Compared with the Iberian Experience". Its contents are the sole responsibility of the author and do not in any way represent the views of the Commission or its services or ZEW.

${ }^{2}$ Similar results have been reported by Storm \& Terrell (1999) for the Czech Republic and by Foley (1997) for Russia.

${ }^{3}$ Teixeira (2000) reports that although restructuring commenced in, for example, the Iberian agricultural sectors during the pre-accession period, it would appear to have accelerated somewhat after accession: employment falling $44 \%$ in Spain, and 54\% in Portugal over the period 1985-1993, compared to rates of $18 \%$ and $29 \%$ in the pre-accession period (1975-1985).

${ }^{4}$ It is important to note that whilst the experience of the later entrants, such as Portugal and Spain, offers some benchmark for assessing the likely ramifications of EU accession for both Poland and the other aspiring entrants, full
} 
the fact that the ramifications for the labour market of the loss of autonomy over monetary policy, which full EU integration ultimately implies, will to a large extent depend on the availability and effectiveness of other adjustment mechanisms, such as factors of production, prices and wages. The brunt of this task, as is evident from the existing literature on the costs and benefits of monetary union, does however, tend to fall on labour ${ }^{5}$. Ensuring that the labour market is able to cope with the additional demands that accession and ultimately monetary union is likely to impose on it, should therefore become a policy objective. The successful attainment of this objective requires however, an in-depth knowledge of the underlying dynamic behaviour of the Polish labour market, so that the so-called "problems areas" can be identified and the appropriate remedial measures introduced in the pre-accession period.

The objective of this study is to take a closer look at labour reallocation process in Poland. Two aspects of the underlying dynamic behaviour of the Polish labour market would appear to be relevant to this issue at this moment in time. The first is to provide some indication as to the degree of mobility in the labour market, thereby offering some evidence as to the likely ramifications for the labour market of the loss of monetary autonomy. In particular, to determine whether labour market turnover increased dramatically, as one might expect, after the initial introduction of a market economy. For, it could be argued that whilst one might expect to observe a significant increase in labour market mobility over the medium to long term, the relatively low rates observed in the formerly planned economies in the early stages of transition may not be that surprising given:

a) that despite the formal adoption of a market economy, privatisation and other major labour market reforms did not begun in earnest in the majority of these economies until after the initial transition period; and b) the unprecedented increases in uncertainty with respect to future economic conditions that undoubtedly occurred with the introduction of the new regime. The second is to identify the demographic, economic and social attributes which either aid or inhibit the effective reallocation of labour.

The remainder of this work is organised as follows. The following section offers a brief overview of labour market trends in Poland during the period 1990-1998, in order to provide some background for the interpretation of the results of our empirical analysis ${ }^{6}$. In section 3 , evidence as to the extent and nature of aggregate labour market mobility across the standard labour market

integration at this stage of the Union implies an unprecedented degree of economic integration for the entrant. Using the experience of previous entrants is therefore, likely to significantly under-estimate the ramifications of accession.

${ }^{5}$ The available empirical evidence highlighting the fact that: a) wages are not particularly flexible, especially in the downward direction and thus cannot be considered to be an effective adjustment mechanism; b) adjustments in physical capital, by their very nature, tend to occur with a relatively long lag, thus severely restricting the ability of physical capital as an adjustment mechanism; c) whilst in theory capital flows are potentially a very effective adjustment mechanism, in practice they tend to over-adjust and thus tend to have a destabilising effect on the economy.

${ }^{6}$ A more in-depth discussions of the developments in the Polish labour market can be found in the annual OCED surveys on Poland and the references contained therein. 
states is obtained by estimating aggregate transition matrices across the traditional labour market states during the period 1994-1998, a period uncovered by these earlier studies. An interesting byproduct of this analysis is that it also enables us to assess the extent to which the reallocation which has taken place is efficient. From an efficiency perspective, interest centres on the extent to which transition and the subsequent structural change results in excessive movements to non-employment states. In section 4, a micro-econometric analysis of the reallocation of individual workers is presented in an attempt to identify the social, economic and geographical attributes which either aid or inhibit the labour reallocation.

\section{The Performance of the Polish Labour Market 1990-1998: some stylised facts.}

Despite a sizeable contraction in the early transition period (1989-1991), Poland's performance in terms of economic growth has been quite remarkable: average growth rates running in excess of 5\% per annum over the period 1992-1998. Interestingly, industry, in particular private industry, has been the major driving force behind this record growth: the manufacturing sector contributing to more than $60 \%$ of the cumulative increase in value added during the period 1992$1998^{7}$. The subsequent fall off in growth rates witnessed over the latter years can largely be attributed to the general slowdown in both Western Europe and Russia, together with the introduction of a number of financial policies to restrain domestic demand.

Labour market performance has been somewhat less spectacular. Employment levels declined in all sectors, with the exception of Commerce and Trade, Public Administration and Finance and Insurance during the initial transition period (1990-1992). This reduction was, however, due to labour hoarding by firms, the continued existence of soft budget constraints and a series of political and social policies which prevented firms from laying off workers, nowhere near that of output ${ }^{8}$. This situation was reversed somewhat in 1992, when the relaxation of a number of employment protection regulations, together with the introduction of an over generous unemployment benefit system resulted in unprecedented increases in unemployment. It is not until 1994 that the unemployment situation stabilises somewhat, with the gradual tightening up of the benefit system and the continual growth of the economy. Yet, despite the significant increases in growth over the period 1994-1998, one fails to observe, due to the continual hoarding of and significant increases in labour productivity levels, a more significant recovery in aggregate employment levels. Unemployment has remained therefore, at a relatively high level compared to EU member states, despite the fact that, as evident from Table 1, the structure of unemployment in terms of age, sex education and occupation, is very similar.

\footnotetext{
${ }^{7}$ The share of the private sector in total output rose considerably during this period reaching $70 \%$ in 1998 .
} 
Labour market performance has also varied substantially within Poland, with unemployment rates in particular, varying considerably across regions ${ }^{9}$. As in other transition economies, regions dominated by either heavy industry or agricultural, or being dependent on a single enterprise have tended to experience larger than average unemployment rates. Regional imbalances have remained relatively stable during the 1990s, with significant differentials persisting even between regions located relatively closely to one another. Such persistence would appear to suggest the existence of a number of rigidities, of which housing is undoubtedly one of the most important ${ }^{10}$. Labour market segmentation at the regional level is further reinforced by the co-existence of poor communication systems, which together with the considerable distances involved, renders commuting extremely difficult and result at the regional level in significant levels of mismatch between demand and supply.

Aggregate indicators of this nature can however, be misleading if they fail to correctly capture the dynamics occurring at lower levels of disaggregation. Gora's (1995) estimates of the degree of industrial turbulence in Poland over the period 1991 to 1992 for example, indicate a surprising degree of dynamism at the sectoral level: estimates of $3.7 \%$ to be compared to the 0.5 $1.5 \%$ registered by OECD members during the 1980's. Similarly, work by Bednarski (1997), indicates that 1,069,000 jobs were actually created during period 1990-1994, of which only 342,000 were as a result of privatisation or sector assignment. This momentum for change in the sectoral composition of Polish employment can be seen to have continued even after the initial transition period, in that one observes: i) a particularly strong expansion in the service related industries: employment in the financial intermediation sector increasing by almost $41.5 \%$; ii) a decline in the more traditional industries: this tendency being particularly large in the mining and quarrying sector $^{11}$. Yet, despite rapid growth rates in a number of those directly affected by the introduction of market forces, these sectors still account for a relatively small proportion of overall employment in Poland which remains dominated by the more traditional industries. Nonetheless, in contrast to the picture obtained from aggregate indicators, the individual sector employment growth rates reported in Table 2, tend to suggest a not insignificant amount of reallocation during the post transition period, with relatively large numbers of individual leaving the more traditional sectors and a constant inflow into the more service orientated employment.

\footnotetext{
${ }^{8}$ Aggregate employment levels declining by $10.2 \%$ during the period $1989-1992$, compared to the $18.6 \%$ reduction in output.

${ }^{9}$ Dispersion in unemployment rates across regions over the period 1994-1998 estimated to be equal to $9 \%$, compared to rates of: 3.01\% for France, 5.15\% for Germany, 12.85\% for Italy, 6.03 for Great Britain during the 1980's.

${ }^{10}$ The continual existence of a heavily subsidised public housing sector, together with: i) the inadequate supply; and ii) the poor quality of the existing housing stock, serving to act as a effective deterrents to the migratory flows required to offset regional differentials.

${ }^{11}$ It is interesting to observe that employment in the agricultural sector actually increased by $2.9 \%$ during these six years. This undoubtedly reflects the phenomenon of hidden unemployment, which has become increasingly more prevalent in Poland during this period.
} 


\section{Aggregate Labour Market Mobility:}

\subsection{Data and Methodology:}

The empirical analysis of this section is carried out using individual data from the Polish Labour Force Survey (PLFS), a household based survey, in which approximately 22,000 households (circa 55,000 individuals) are interviewed on a quarterly basis ${ }^{12}$. The PLFS, introduced in May 1992, is carried out according to a standard 2 (2) 2 rotation system. In other words, a household is interviewed in two consecutive quarters, then drops out for the next two quarters and is re-sampled for a further two quarters, before permanently leaving the sampling frame ${ }^{13}$. The rotating characteristic of the PLFS is such that one is able to match records for the same individual across two consecutive surveys and then to observe them 6 months later, when they re-enter the sampling frame for a further two quarters. Thus in any given quarter, researchers should in theory have access to the previous quarter's records for $75 \%$ of the respondents and are also able to match files for $50 \%$ of the current month's survey with the survey in the same quarter of the following year.

The PLFS, as other national labour force surveys, adopts the International Labour Organisation's recommendations for the assignment of labour market status ${ }^{14}$. This classification results in nine labour market transition probabilities, which can be represented by the following standard labour market transition matrix:

$$
P=\left[\begin{array}{lll}
P^{e e} & P^{e u} & P^{e o} \\
P^{u e} & P^{u u} & P^{u o} \\
P^{o e} & P^{o u} & P^{o o}
\end{array}\right],
$$

where: $e, u$ and $o$, represent the labour market states: employment, unemployment and out of labour force; the initial superscript refers to the individual's labour market state in $t$ and the latter to his state in $t+12$ months. $P^{e u}$ therefore, represents the probability of observing an individual in employment in time $t$ and as unemployed in $t+12$ months. This standard classification is however, likely to under-estimate the degree of adjustment occurring in the labour market at any specific moment in time, since it fails to capture those individuals who, whilst remaining in the stock of

\footnotetext{
${ }^{12}$ The survey does not, however, cover those members of the household currently residing abroad or people living in dormitories or military barracks.

${ }^{13}$ A more in-depth discussion of the structure and sampling design of the Polish labour force survey can be found in Szarkowki \& Witkoswki (1994) .

${ }^{14}$ Thus an individual is classified as employed if during the reference week, he: i) received money for at least one hour work; ii) had a job, but for some temporary reason (illness, strike etc.) did not actually work; and iii) was engaged in a family enterprise or farm, but was not actually paid. An individual is deemed to be unemployed, if during the reference week he was not employed according to the aforementioned criteria, but was engaged in some form of active job search activity and was available to commence employment in either the week of the survey or the one immediately after it. Finally, individuals are classified as being out of the labour force if they do not fulfil either of the aforementioned criteria.
} 
employment, actually move from one job to another. In an attempt to assess the extent to which structural adjustment in Poland results in employment to employment, as opposed to employment to non-employment transitions, the probability of transiting from one job to another, $P^{e e e}$, is also considered. Employment to employment transitions being identified on the basis of reported tenure data.

Under the standard Markov assumption that the probability of making a transition depends only on an individual's current labour market status, the probability of observing an individual in state $j$ in period $t+12$, conditional on him being in state $i$ at period $t$, is given by:

$$
P_{i j}=F_{i j} / S_{i} \quad, i, j=e, u, o,
$$

where: $F_{i, j}$ denotes the number of individuals observed in state $i$ in the first period and in state $j$ in the second; and $S_{i}$ is the stock of individuals in state $i$ in the initial period. Changes in labour market status (transitions) are identified by comparing the observed labour market status of individuals in $t$, with that observed in $t+12$. A person is deemed to have changed labour market state, if his observed labour market status in the latter period differs from that of the original one. A job to job transition is recorded if an individual is observed as being employed in period $t$ and $t+12$, but reports continuous of less or equal to 12 months in $t+12^{15}$.

\subsection{Results:}

As is evident from the data presented in Table 3, the year to year changes in the distribution of individuals across labour market states would, with the exception of unemployment, tend to suggest rather sluggish adjustment. As existing studies of worker flows have shown however, the sluggish nature of labour market stocks observed in the majority of industrialised economies, tends to mask a surprisingly high degree of fluidity in the underlying flow data ${ }^{16}$. To determine whether this apparent lack of variability in the Polish stock data is indicative of a relatively immobile work

\footnotetext{
${ }^{15}$ The problems associated with the use of quasi-panel, such as the Polish LFS, in order to identify labour market transitions and the subsequent biases that may be introduced into any empirical analysis of labour force dynamics carried out, as in the analysis in hand, using raw labour force survey data are well documented in the literature (see for example Artola \& Bell (1999)). The available evidence for Poland, whilst extremely scarce, indicates that these problems are also inherent in the Polish LFS data. Work by Szarkowki \& Witkoswki (1994) suggests that the extent of sample attrition in Poland is sizeable: with between 3.9\% and 6.5\% of all households who in theory should have been included in the PLFS over the period May 1992 to November 1993, not responding to the survey. Moreover, the authors find that Polish non-response rates exhibit a considerable variation across community size, with the rates in the largest cities being surprisingly high: in Warsaw for example, an average non-response rate of $24 \%$ is recorded for this period. It would not appear that unreasonable to expect the characteristics of the non-respondents in these cities to be considerably different from those elsewhere. In other words, sample attrition in the PLFS would appear to be nonrandom.

${ }^{16}$ See for example, Antolìn (1996), Gomez-Salvador \& Dolado (1995), Burda \& Wyplosz (1993) and Blanchard \& Diamond (1990).
} 
force or whether it does in fact disguise a considerable amount of worker turnover at the more disaggregate level, aggregate labour market transitions were estimated for the period November 1994 to November $1998^{17}$. More specifically, the analysis of this section is based on the matched observations of individuals across the following periods: November 1994-November 1995; November 1995-November 1996; November 1996-November 1997 and November 1997-1998 ${ }^{18}$. The November wave of each year was chosen in an attempt to minimise the seasonal effects present in the underlying data. This selection criteria results in a sample of just over 25,000 individuals in each of our sub-periods ${ }^{19}$.

A number of particularly striking features emerge from the estimated transition rates reported in Table 4. Firstly, the persistent nature of the labour market stocks does appear to offer a relatively accurate portrayal of the underlying dynamic behaviour of the Polish labour market. The high values obtained for the diagonal cells of the Polish transition matrix and in particular for employment and out of the labour force, implying a relatively low level of mobility. Moreover, these transition rates would appear to be lower than those reported in a number of industrialised countries, which have not been faced with anywhere near the degree of adjustment experienced in Poland during this period. As is evident from table 5, considerable differences do however, exist in transition rates across both age and gender. As in other industrialised countries, women tend to exhibit relatively weaker levels of labour force attachment than men, with this probability increasing slightly over the sample period ${ }^{20}$. Whilst one does not observe significant differences in the employment retention rate between the sexes over our sample period, there does appear to be a significant difference in the destination states of men and women leaving employment. In 1994 for example, of those women leaving employment $68 \%$, compared to only $47 \%$ of men, dropped out of

\footnotetext{
17 The readers attention is drawn to the fact that these estimates have not, due to the lack of available data, been corrected for problems of attrition, misclassification error or round-tripping.

${ }^{18}$ In May 1994, considerable changes were made to the structure of the PLFS. More specifically: i) NACE industrial codings replaced the previously used Polish industrial groupings; and ii) a number of changes were made to the occupational groupings. As changes of this nature are likely to result in a considerable amount of noise, which can be neither measured nor controlled for, being introduced into studies covering the whole period (1992-1998) for which the survey is available, this analysis is restricted to the period 1994-1998 for which a more homogenous survey is available. Moreover, information on tenure, used to identify job to job transitions, was only introduced in August 1994.

${ }^{19}$ It was decided at the outset to match individual records across yearly, as opposed to quarterly intervals in order to: i) minimise the seasonal variation in transitions; and ii) maximise the number of cell counts in each of our sample periods. The use of annual, as opposed to quarterly, matching of individual files does tend to exacerbate the problem of roundtripping. Work by Gora \& Lehman (1995) using the true panel component of PLFS (the first 4 quarters of the survey) illustrate however: i) that even when one is able to follow individuals continuously at quarterly intervals one cannot completely avoid the problem of round-tripping; and ii) that the relevance of this phenomena tends to depend on the original labour market status of the individual. Round-tripping does not for example, appear to be a significant problem in the case of employment and out of the labour force related transitions, with only $(3.8 \%)$ of such individuals transiting and then returning to their original state during the period under consideration. Round-tripping on the other hand, is found to be a significantly more important phenomenon for the unemployed, with approximately $23.8 \%$ of these individuals being engaged in round tripping over the sample period. These magnitudes will need to be borne in mind when considering estimates of aggregation gross transitions.

${ }^{20}$ This trend may however, reflect the fact that in the post-communist economy, women are finding it increasingly more difficult to reconcile employment and family obligations (Foley 1997).
} 
the labour force. Moreover, this percentage actually rises throughout the sample period, reaching $71 \%$ in 1998. Similarly, whilst the probability that a female is observed unemployed at the beginning of the year and then again a year later, is not considerably different from that of males (although once again this difference widens over the sample period from 0.66 percentage points in 1994 to 4.36 in 1998). Decomposition of the unemployment related transitions indicates: i) that men are more likely to exit unemployment to employment than women; and ii) that once they have left the labour force, women also have a slightly higher probability of remaining there. Thus although the risk of losing employment is only slightly higher for women, once lost, Polish women in common with their European counterparts, find it relatively more difficult to find re-employment ${ }^{21}$.

Whilst the unemployment stock appears at first glance to be significantly more dynamic than the other labour market stocks, the estimated unemployment retention probabilities, despite the relatively larger flows into and out of the unemployment stock, suggest an underlying average unemployment duration of approximately two years ${ }^{22}$. Moreover, the more recent increases in the unemployment retention probability, together with the subsequent decline in the unemployment to employment transition rate, highlight a deterioration in the unemployment situation. Yet, despite these more recent developments, the fact that the majority of outflows from unemployment were actually to employment, suggests that the considerable reduction in unemployment in Poland during the period 1994-1998 was associated with an overall improvement in the labour market situation; reflecting transitions to employment, as opposed to withdrawals from the labour force.

Despite this lack of variability, an analysis of the behaviour of the off-diagonals elements of the Polish transition matrix does provide a number of interesting insights into the underlying labour force dynamics, which can be of particular importance to the policy debate. More specifically, it can: i) provide further information as to the extent to which the reallocation which has taken place is efficient; and ii) help to identify those groups, which find it relatively more difficult to maintain links with the labour force in the aftermath of job loss.

Two aspects of the reallocation process are of relevance to an assessment of its overall efficiency. The first is the proportion of job to job transitions relative to the total number of transitions: a more efficient reallocation argued to be one which results in a relatively higher number of employment to employment transitions and a lower number of employment to nonemployment transitions ${ }^{23}$. The second is related to the distinction between desirable and undesirable

\footnotetext{
${ }^{21}$ These differences would not appear, from the values of estimated transitions rates disaggagregated according to age, to be simply due to gender specific issues, such as women of child bearing age leaving the labour force for maternity reasons.

${ }^{22}$ To be compared for example, to approximately 6 months in Germany.

${ }^{23}$ This is however, only one, and arguably the least refined means of assessing efficiency, since it fails to account for the quality of the job involved in the employment to employment transition. Thus by its very nature, it does not allow for the fact that some individuals may prefer to take a more menial or a lower standard of job than previously held in order to remain in employment.
} 
labour reallocation: a "desirable" reallocation process being one in which labour shifts towards productivity increasing firms or industrial sectors and "undesirable, to productivity decreasing ones.

If we initially consider those individuals who, whilst remaining employed, actually changed job (between $5 \%$ and $4.3 \%$ of individuals during the sample period ${ }^{24}$ ), it is evident that the restructuring which has taken place in Poland has tended to result in more transitions to nonemployment states than employment to employment transitions. Of those individuals which left employment over the period 1994 to 1998, between 60\% (1994) and 67\% (1998) actually dropped out of the labour force. This latter finding, together with the fact that on average only $40 \%$ of individuals leaving their original employment position during our sample period actually managed to immediately find another one, would tend to suggest that the labour reallocation which occurred in Poland during this period has not been that efficient. In that the reallocation which has taken placed has been dominated by a disproportionate number of transitions to non-employment, in particular, to out of the labour force. An additional worrying aspect of this trend is the fact that once these individuals actually drop out of the labour force, the probability that they remain there is extremely high. Moreover, this probability has steadily increased throughout the sample period, from $92 \%$ in 1994 to $94 \%$ in 1998 . On a more positive note, if one uses the public/private sector distinction as a proxy, albeit a somewhat crude one, of declining and increasing productivity sectors, the reallocation which has taken place until now would appear to be relatively desirable - in that $77 \%$ of employment related reallocation is found to have been directed towards the private sector. From this perspective then, although somewhat limited in absolute terms, the employment related labour reallocation which has taken place would appear to be relatively desirable.

An important finding which emerges from these results is that aggregate mobility patterns do not appear to be significantly affected by prevailing economic conditions. In that the observed transition probabilities would appear to be relatively similar across very different phases of the cycle. During the first four years of transition, the Polish labour market was characterised by a reduction in employment and unprecedented increases in unemployment, from 1994 however, the economy experienced a remarkable recovery (growth rates averaging at $6 \%$ per annum over the period 1994-1998) during which considerable reductions in the unemployment rate were obtained. Somewhat surprisingly, this turnaround of events is not reflected in observed mobility patterns, which do not appear to have changed significantly during this period. Furthermore, one does not observe the expected increase in mobility over time, despite fact that by 1997-1998 the transition process can be considered to be well and truly under way. If anything, the observed retention rates actually suggest a reduction in mobility during the period considered: with a general increase (of

\footnotetext{
${ }^{24}$ Slightly lower than the $5.4 \%$ reported by Lehman \& Wadsworth (1997) for the period 1994-1996.
} 
between 2 and $4 \%$ ) in the probability of remaining in one's initial state being observed ${ }^{25}$. Perhaps the most worrying, although the magnitudes involved are relatively small, of these developments is the aforementioned decline in transitions from the unemployment stock and in particular transitions to employment.

The insensitivity of mobility to economic conditions not only questions the ability of labour to act as an effective adjustment mechanism, but suggests the existence of a number of underlying rigidities in the labour market which hinder the reallocation process. Factors, such as institutional constraints (i.e. employment regulation or powerful trade unions), over generous transfer payments (such as unemployment benefits and/or pension provisions), skill mismatch as a result of human capital inefficiencies, a relatively compressed wage distribution and last, but not least, the absence of an efficient housing market have repeatedly been blamed by observers (see for example, OECD (1998)) for the lack of labour mobility in the formerly centrally planned economies. Whilst the framework in which the analysis of this section has been carried out does not in itself permit us to directly assess the individual impact of each of these factors on the reallocation process itself, the estimation of a number of transition probabilities at a more disaggregated nature can help to shed further light on the relevance of some of these.

One immediate explanation which springs to mind for the apparent insensitivity of aggregate mobility patterns to economic conditions, is that the transition has resulted in the emergence of a pool of individuals who have in effect become "outsiders", findings themselves, due to human capital considerations, unable to compete in the more competitive market orientated system. If this is indeed the case, unemployment is to be considered a result of skill mismatch or more generally, deficiencies in stock of human capital and not a consequence of insufficient demand. Transition rates disaggregated according to education level offer some support for this hypothesis: in that approximately $30 \%$ of all employment to non-employment transitions and $63 \%(30 \%)$ of those individuals classified as being out of the labour force (unemployment) for more than one year, are accounted for by individuals with primary or lower levels of completed education. These figures are to be compared with those for the highest skilled individuals (those with at least a post secondary level of completed education), who account for only: i) $10.84 \%$ of total employment to nonemployment transitions; and ii) $2.81 \%(4.03 \%$ ) of those individuals with unemployment (out of the labour force) retention probabilities in excess of one year. Furthermore, the finding that workers employed in larger firms appear to find it relatively more difficult to find immediate re-employment in the aftermath of job loss, would tend to offer further support for the skill mismatch argument that

\footnotetext{
${ }^{25}$ Note that the retention rates obtained here suggest a slight increase in the degree of mobility over that reported for the period 1992-1993 by Steiner \& Kwiatkowski (1995). Whilst, the estimated employment and out of the labour force retention rates are somewhat lower than those obtained by Gora \& Lehman (1995), some of this difference may be due
} 
a considerable proportion of individuals employed in the more traditional heavy industries (which tend to dominate the large scale enterprise sector) do not have the skills requisites demanded by the newly expanding sectors, where employment growth tends to be concentrated.

The estimated transition probabilities disaggregated according to firm size, sector and employment contract status presented in Table 6, would appear to be consistent with the argument that powerful trade unions, together with over protective employment legislation for full-time permanent employees, have contributed to minimising the impact of the restructuring process in Poland, particularly in large and public sector enterprises. Estimated employment retention rates being considerably higher for: i) full-time and public sectors workers; and ii) individuals employed in large scale enterprises. It is well documented that these individuals are in fact the ones which, not only tend to be relatively more protected by existing employment protection legislation, but are also employed in sectors with a relatively strong trade union presence. It is important to note that the relative inherent immobility of public sector workers is likely to be exacerbated by the fact that the majority of these workers are, in addition to other social benefits - such as the provision of child care, health and recreational facilities - still provided with low cost housing, a remnant of the socialist regime.

Finally, labour market policies can, by their very nature, themselves have a profound impact on the labour market behaviour of specific groups. As is evident, from the estimated transition rates disaggregated according to age reported in Table 5, the establishment of a relatively generous pension system, together with the introduction of a number of over generous early retirement schemes was been accompanied by significant increases in both labour market withdrawals and out of the labour force retention rates for the pre-retirement age group (55-65 years) and the 46-54 year age group. Moreover, the subsequent fall in transition probabilities observed during the latter half of the sample period occurred during a period in which the generosity and promotion of these schemes was considerably curtailed. Similarly, the introduction of a over generous unemployment benefit system is found to have been accompanied by an increase in both transitions to unemployment and unemployment retention rates. The steady decline in transition rates to unemployment observed from 1995 onwards, again occurred during a time which the system was steadily being made more stringent (in terms of both eligibility conditions and generosity of payments) in order to bring it into line with EU unemployment compensation schemes.

It is interesting to note how these transitions probabilities compare with those observed in other transition economies. As is evident from the results of existing studies of this nature presented in the lower panels of Table 4, turnover rates in these countries are actually relatively similar. If one 
compares the Polish results to those of the Czech Republic, where the analysis was carried out over the same time period, the smaller aggregate retention probabilities observed in Poland would tend to suggest a slightly higher degree of reallocation in Poland vis-à-vis the Czech Republic ${ }^{26}$. Moreover, the fact that: i) estimated job to job transitions are on average somewhat higher in Poland ${ }^{27}$; ii) individuals dropping out of the Polish labour force are found to have a slightly higher probability than their Czech counterparts of reintegrating themselves back into the labour market; and iii) Poland has yet to experience the significant declines in the exit probability from unemployment observed in the Czech data, suggests that worker reallocation has tended to be relatively less costly in Poland. The Polish labour market does however, appear to be less flexible (in terms of worker reallocation) vis-à-vis the Russia one. The estimated transition rates reported in Foley (1997) implying a significantly faster pace of worker reallocation in Russia than Poland, where the reduction in manufacturing employment and the expansion in the service industries have been considerably lower.

\section{The Determinants of Individual Mobility:}

Whilst an aggregate analysis of the form undertaken in the previous section provides general information on both the overall level of mobility and the labour market behaviour of specific groups, as with any aggregate analysis, it is however, likely to disguise important differences across different demographic, economic or social characteristics which could offer further insights into our understanding of the labour market behaviour of specific groups. Moreover, disaggregated information of this nature is essential to the formulation of effective active labour policy, since it enables one for example, to identify those individuals who either: i) experience relatively more difficulty in successfully securing employment; or ii) are more likely to become marginalised from the labour force in the aftermath of the loss of employment and on whom labour market policy might therefore, be more effectively targeted.

According to standard random utility theory, an individual will evaluate the costs and benefits of changing his labour market state and change, if and only if, the benefits outweigh the costs of doing so. In a multiple choice environment, the probability that for an example, an employed individual in period $t$ changes labour market status will be given by ${ }^{28}$ :

\footnotetext{
${ }^{26}$ The higher employment retention rates of the Czech Republic could be a reflection of the fact that firms had not yet fully embraced the restructuring programs necessary to compete in a market economy.

${ }^{27}$ Storm \& Terrell (1999) report job to job transition rates for the Czech Republic of: 2.5\% in 1994; 5.8\% in 1996; and $3.5 \%$ in 1998 .

${ }^{28}$ Due to the discrete nature of the labour force survey data, multi-nomial probabilities, as opposed to hazards, are estimated.
} 


$$
\operatorname{Pr} o b\left(Y_{i}=j\right)=\frac{\operatorname{Exp}\left(B_{j}^{\prime}, X_{i}\right)}{\sum_{k=1}^{4} \operatorname{Exp}\left(B_{k}^{\prime}, X_{i}\right)}, \quad j, k=1,2,3,4
$$

where: $X$ is a vector of individual, job and regional specific characteristics; and 1, 2, 3 and 4 refer, in the case of employment related transitions, to the following possible labour market states: 1 remaining in one's original labour market status; 2, remaining employed, but changing job; and 3, transiting from employment to unemployment; and 4 transiting from employment to out of the labour force. The respective log likelihood of which is given by:

$$
\ln L=\sum_{i=1}^{n} \sum_{j=1}^{4} D_{i j} \operatorname{Ln} \operatorname{Prob}\left(Y_{i}=j\right) \text {, }
$$

where $D_{i j}$ is equal to 1 if the individual is observed in state $j$ and zero otherwise.

In contrast to the analysis of the preceding section, the empirical analysis is undertaken using the matched individual records over the period November 1994-November 1995 and November 1997-November 1998. These two waves are of particular interest, since they enable one to take a closer look at the determinants of individual mobility behaviour at two very different stages of both the business cycle and the transition period. The sample is further restricted to individuals aged between 15-65 years of age ${ }^{29}$. These selection criteria result in a sample of approximately 21,500 individuals in both waves, of which an average of: 11,874 were observed as being employed in period $t^{30} ; 1,569$, as being unemployed; and 7,749 as being out of the labour force.

In addition to the standard individual (age, sex, civil status, educational attainment, occupation and duration of current state) and job (firm size and sector) characteristics which might be expected to influence an individual's decision to change his current labour market status, the impact of changes in local economic conditions are also assessed through the inclusion of regional unemployment and vacancy rates in the empirical model to be estimated. It is assumed, as is often the case in migration analysis, that the mobility decision is affected by economic information prior to those available at the time of the decision. More specifically, the economic conditions argued to be relevant to the individual's decision-making process are the annual averages of those prevailing in the year prior to the actual transition. A set of regional dummies is also included in the regressions to allow for regional specific effects.

\footnotetext{
${ }^{29}$ Although the statutory retirement age is 59 for woman and 65 for men, continual labour market participation of individuals outside this age band is observed throughout the sample period. On the basis of these observations a more appropriate age bracket to consider would appear to be the 15-65 age group.

${ }^{30}$ The sample of individuals observed as employed in period $t$, is further restricted to either employees or self-employed in the first period of each of our samples. Individuals classified as being unpaid family help are therefore, due to their often erratic behaviour, excluded from our sample.
} 
The marginal effects obtained from the maximum likelihood estimation of equation 2, reported in Tables 7 to 10, tend to be fairly consistent with a priori expectations based on existing work on individual's labour market behaviour. Age is on the whole, found to be an important determinant of mobility in Poland:: i) younger (older) workers are found to be relatively more (less) likely to either change employment or become unemployed, particularly at the beginning of the sample period; and ii) older workers are relatively more likely to withdraw from the labour force in the aftermath of employment loss. This latter tendency undoubtedly reflects the generous early retirement packages which were particularly prevalent at the beginning of our sample period. Age would also appear to be an important determinant of labour force attachment: younger (older) age groups being relatively more (less) likely to transit to employment or unemployment from out of the labour force, than prime age workers. Age per se, would however, appear to be a relatively less important determinant of unemployment related labour reallocation $\left(\mathrm{P}^{u e}\right.$ and $\left.\mathrm{P}^{u o o l}\right)$. The estimated transitions probabilities indicating that although, older individuals are found, at the beginning of the sample period, to be relatively less likely to transit to employment and relatively more likely to withdraw from the labour force, the young would not appear to exhibit systematically different significant behaviour from that of prime aged individuals.

Significant differences are also observed in mobility behaviour across both civil status and gender. Focusing initially on the employment related transitions $\left(\mathrm{P}^{e e e}, \mathrm{P}^{e u}\right.$ and $\left.\mathrm{P}^{e o o l}\right)$, it is worth noting that single women are not, with the exception of employment to employment transitions, found to exhibit significantly different mobility behaviour than men. In common with findings for a number of industrialised countries, married women on the other hand, are found to: i) be the least mobile; and ii) exhibit a relatively weaker labour force attachment than either men or single women. In terms of the unemployment related transitions, married women are again found to: i) exhibit relatively weaker labour force attachment than either men or their single counterparts; and ii) be relatively less likely to transit to employment. Married men on the other hand, tend to be relatively more likely to transit to employment than their single counterparts. Somewhat surprisingly, the results obtained for the out of the labour force related transitions $\left(\mathrm{P}^{\text {oole }}, \mathrm{P}^{\text {oolu }}\right.$ and $\left.\mathrm{P}^{\text {ool }}\right)$ indicate that civil status and gender cannot be considered as important determinants of an individual's relative probability of re-entering the labour market. The only significant difference being that married men are found to be relatively more likely to transit to unemployment than their single counterparts. This latter result is likely to be driven by the issue of benefit eligibility.

Education is found to be an important determinant of both employment and unemployment related transitions. Whilst, education per se does not appear to have a significant impact on an individual's relative likelihood of moving from one job to another, human capital is an important determinant of employment attachment: individuals with university or higher levels of education 
being found to be relatively less likely to transit from employment to a non-employment state ${ }^{31}$. Educational attainment is also fundamental to unemployment to employment transitions: individuals with more than a basic level of education (elementary or less) being relatively more likely to successfully transit from unemployment to employment. Moreover, this effect is found to be an increasing function of the education level itself. It is interesting to note that educational attainment has little impact on labour force attachment: with only the very highly educated being relatively less likely to transit from unemployment to out of the labour force. The accumulation of human capital is however fundamental to the successful integration of an individual into the work force: those individuals with higher levels of education than the base group, being more likely to successfully transit to employment. Again, this effect is increasing in the level of education. Educational attainment would appear however, to be of little relevance to transitions from out of the labour to unemployment.

The results of the employment related regression, presented in Table 7 and 8, suggest the existence of an inverse relationship between mobility and occupational categories: in that more highly skilled individuals (in terms of occupational groupings) tend to be considerably less mobile than their lower skilled counterparts. Interestingly, an individual's occupation is not found to have a significant effect on the relative likelihood of labour force withdrawal at the beginning of the sample period. By 1998 however, occupation is found to be a small, but fairly significant, determinant of employment attachment: unskilled workers being found to be relatively more likely to withdraw from the labour force than their skilled counterparts. In common with findings for other countries, mobility is found to be inversely related to both tenure and firm size: individuals with relatively shorter tenure profiles or employed in smaller size enterprises being relatively more mobile. The significance of this latter effect does however, tend to die out somewhat over the sample period. The results of the employment related transition regressions would also appear to suggest that the assumption that it is the private sector, in economies in transition, which tends to be more dynamic, is somewhat misplaced. In that the behaviour of public sector employees is only found to systematically differ from that of private sector employees based in the construction industry: these workers being relatively more likely to change employment or withdraw from the labour force than their public sector counterparts.

Whilst previous work experience in itself increases the relative likelihood of both labour force re-entry and of an unemployed individual finding employment, previous occupation appears

\footnotetext{
${ }^{31}$ See OECD (1992) for an in-depth discussion of the Polish education system during this period. To ease interpretation of the empirical results, note that the number of years of completed education associated with each of the Polish education levels is as follows: elementary school education is equivalent to 8 years of completed education; basic vocational school to 10 years; general secondary schooling to 12 years, vocational secondary schooling to 13 years, and post-secondary schooling to 14 years.
} 
to be completely irrelevant to this facet of the reallocation process ${ }^{32}$. Thus it is work experience per se, which would appear to matter to an individual's relative likelihood of transiting from unemployment to employment and not the type of work that the individual previously carried out or the sector in which he was previously employed ${ }^{33}$. This result could be driven by the fact that as the majority of newly created positions tend to be in the rapidly expanding service sectors, which were to all intents and purposes practically non-existent under the previous regime, the occupational match between the older industrial structure and the newer one is likely to be rather poor. Moreover, a large proportion of the newly created jobs in these sectors tends to be of a relatively low skill content and thus special skill requirements are not likely to be a prerequisite for employment. Interestingly, one does not observe the standard duration dependence effects throughout the sample period. For, whilst an individual's relative likelihood of transiting to employment from unemployment is found to be inversely related to duration at the start of our sample period, these duration effects do not enter the regression in a significant manner at the end of the sample period.

In common with the results of section 1, mobility is found, on the whole, to be relatively insensitive to prevailing local economic conditions, as proxied by the regional unemployment and vacancy rates ${ }^{34}$. Whilst a deterioration in local conditions, as captured through an increase in the local unemployment rate, is found to result in the expected reduction (increase) in the likelihood of an employed individual transiting from job to job (unemployment or out of the labour force), the magnitude of these effects is quite limited and in the case of transitions to a non-employment state tends to die out over the sample period. Similarly, although, increases in the regional unemployment rates are found to have the expected negative impact on the probability of transiting from unemployment to employment, this impact is again relatively small and remains relatively constant across our sample period. In other words, increases in the regional unemployment rate would appear to have a similar impact regardless of the prevailing state of the labour market: whether the market is characterised by relatively high and rising unemployment rates or by considerably lower and falling rates.

\section{Conclusions:}

\footnotetext{
${ }^{32}$ Information on previous occupation, sector, length of inactivity spell are unavailable for individuals classified as inactive and thus not included in the estimations of out of the labour force related transitions $\left(\mathrm{P}^{o u}\right.$ and $\left.\mathrm{P}^{o e}\right)$.

${ }^{33}$ Although the estimated marginal effects for wave 1 (1994-1995) indicate that individuals previously employed in the public sector tend to find it relatively more difficult to make the transition to employment and tend to remain unemployed for relatively longer durations than those employed in other sectors, these effects would appear to have withered out by the end of the sample period.

${ }^{34}$ One possible explanation for this lack of a significant vacancy impact is that the Polish official vacancy data, as in other EU countries, only covers vacancies registered at the local employment office, which tend to represent only a small proportion of total vacancies on offer in the economy and by very nature tend to be for low quality jobs.
} 
The estimated aggregate transition rates indicate that despite a number of significant changes in the structure of the Polish labour market during the sample period, aggregate mobility in Poland has remained at a relatively low level. Somewhat surprisingly, the estimated aggregated transition rates are not found to be significantly different from those obtained for the initial transition period. The ramifications of this inherent inflexibility are evident in the significant increase in unemployment experienced in Poland from 1990 to 1994. EU accession is itself likely to result in a considerable increase in the rate of structural adjustment, thus unless significant steps are now taken to improve the overall degree of labour market flexibility in the pre-accession period, the increases in structural change which will inevitably be imposed upon entry to the EU, are likely to result in further increases in unemployment. As the experience of Spain has shown, unemployment could result in accession being an extremely costly, from a social perspective, process. Moreover, the relatively constant transition rates obtained throughout the sample period would tend to suggest that Polish aggregate mobility patterns are not significantly affected by prevailing economic conditions. This finding in itself, raises doubts as to the ability of labour to act as an effective adjustment mechanism in the face of adverse shocks once control of Polish monetary policy has been handed over to the European Central Bank.

The microeconometric analysis of individual labour market transitions serves as a useful starting point for the identification of those attributes which either facilitate or inhibit the effective reallocation of labour. The results illustrate that labour market mobility varies considerably across a number of individual and employment related characteristics. More specifically, age, educational attainment and civil status are found to be important determinants of mobility. The youth labour market is seen to be relatively more dynamic than that of other age groups, this is reflected in both lower employment retention rates and higher transition probabilities between employment and both unemployment and out of the labour force. Perhaps the most "fragile", are those individuals aged 45 years and over: exits from employment for this age group being dominated by flows out of the labour force. Moreover, the estimated out of the labour force transition rates $\left(\mathrm{P}^{\text {oole }}, \mathrm{P}^{\text {oolu }}\right.$ and $\left.\mathrm{P}^{\text {ool }}\right)$ for these age groups suggest that these individuals find it relatively more difficult to re-integrate themselves back into the labour market than younger age groups. The acquisition of human capital is found to be fundamental, not only to the degree of overall reallocation, but also to the very nature of the transitions themselves, this education effect increasing over the sample period. More specifically, the more educated tend to be relatively more likely to transit either from unemployment to employment and perhaps more importantly, to successfully integrate themselves into the workforce. As observed in other industrialised countries, women tend to exhibit weaker labour force attachment than men, a phenomenon which would appear to have increased somewhat over the sample period. Thus, although, the female employment retention rate is only slightly lower 
than that of males, once their employment relationship is terminated Polish women find it relatively more difficult to find another job. Finally, it is interesting to note that having controlled for a number of individual and employment specific characteristics, public sector employees are not systematically found to be relatively less mobile than those individuals employed in the private sector across the sample period.

\section{References:}

Antolìn, P. (1996): “Gross Worker Flows: How Does the Spanish Evidence Fit the Stylized Facts?”, Centre for Economic Policy Research, Discussion Paper No. 1398, May 1996.

Artola, C. and Bell, U.L (1999): "Identifying Labour Market Dynamics using Labour Force Survey Data”, Banco de Espana. Documento de Trabajo, N. 99/22.

Bednarski, M. (1997): "Small and medium companies and active labour market policy in Poland". Mimeo, Department of Economics, Warsaw University.

Blanchard, O. and Diamond, P (1990): "The Cyclical Behaviour of the Gross Flows of US Workers", Brookings Papers on Economic Activity, 1990-2, 85-143.

Boeri, T. and Flinn, C. (1999): "Returns to Mobility in the Transition to a Market Economy", Journal of Comparative Economics, 27, 4-32.

Burda, M. and Wyplosz, C. (1993): "Gross Worker and Job Flows in Europe”, CEPR Discussion paper $\mathrm{N}^{\mathrm{o}} 868$.

Foley, M.C. (1997): "Labor Market Dynamics in Russia", Economic Growth Center Discussion paper, 780, Yale University.

Gómez Salvador, R. and Dolado, J.J. (1995): “Creacion y Destrucción de Empleo en España: Un Análisis Descriptivo con Datos de la CBBE", Banco de España, Servicio de Estudios, Documento de trabajo $\mathrm{N}^{\circ} 9526$.

Gora, M. (1995): “The Labour Market in Poland. A Tentative Analysis of Transition”, Eastern European Economics, pp.75-96.

Gora, M. and Lehman, H. (1995): "How Divergent is Regional Labour Market Adjustment in Poland?" in The Regional Dimension of Unemployment in Transition Countries, OECD.

Lehman, H., Kwiatkowski, E. and Schaffer, M. (1991): "Polish Regional U/V ratios and Pre-reform Employment Structure”, LSE-CEP, Working Paper No. 109.

Lehman, H. and Wadsworth, J. (1997): "New Jobs, Worklessness and Households in Poland", European Economic Review, 41, p. 915-923.

Kwiatkoski, E., Domanski, C. and Kubiak, P. ((1997): "Forms, Principles and Effects of Labour Market Policies in Poland in Transition", mimeo University of Lodz, Poland. 
Kwiatkwoski, E., Kubiak, P. and Kucharski, L. (2000): "Inter-Industry and Intra-Industry Mobility of Labour in Poland 1994-1998”, mimeo University of Lodz, Poland.

OECD (1992): "The Polish Labour Market".

OECD (1992), (1998), (2000): Economic Surveys: Poland.

Steiner, V. and Kwiatkowski, E. (1995): “The Polish Labor Market in Transition", ZEW Mannheim, Discussion Paper No.95-03.

Storm, V. and Terrell, K. (1999): “A Comparative Look at Labor Mobility in the Czech Republic: Where Have all the Workers Gone?”. The William Davidson Institute, University of Michigan Business School, Working Paper No. 140.

Szarkowki, A. and Witkowski, J. (1994): "The Polish Labour Market Survey", Statistics in Transition, 1, 4, p.467-483.

Teixeira, P. (2000): “Labour Market Transition in Portugal, Spain and Poland: A Comparative Perspective". Mimeo Faculdade de Eonomia, Universidade de Coimbra, Portugal.

Wadsworth, J and Lehman, H. (1999): "Tenures that Shook the World: Worker Turnover in Russia, Poland and Britain", mimeo CEP. 
Table 1

The Structure of Polish Unemployment: 1994-1998

\begin{tabular}{|c|c|c|c|c|c|}
\hline & 1994 & 1995 & 1996 & 1997 & 1998 \\
\hline \multicolumn{6}{|l|}{ Sex } \\
\hline Males & 46.04 & 48.35 & 46.5 & 47.48 & 39.43 \\
\hline Females & 53.96 & 51.65 & 53.5 & 52.52 & 60.57 \\
\hline \multicolumn{6}{|l|}{ Age } \\
\hline Less than 25 years & 29.21 & 29.53 & 32.95 & 36.11 & 30.47 \\
\hline 25-34 Years & 26.05 & 26.81 & 24.03 & 21.22 & 21.86 \\
\hline \multicolumn{6}{|l|}{ 35-44 Years } \\
\hline 45-55 Years & 10.57 & 10.25 & 10.22 & 9.77 & 12.54 \\
\hline$>55$ years & 4.11 & 3.24 & 2.45 & 2.98 & 2.87 \\
\hline \multicolumn{6}{|l|}{ Education } \\
\hline Primary or Less & 22.29 & 24.2 & 24.81 & 25.80 & 18.28 \\
\hline Basic Vocational & 44.99 & 44.55 & 42.68 & 40.84 & 46.95 \\
\hline General Secondary & 7.06 & 7.06 & 6.52 & 8.24 & 9.32 \\
\hline Secondary & 21.34 & 15.4 & 21.46 & 20.38 & 19.35 \\
\hline Post-Secondary & 2.00 & 2.32 & 2.57 & 2.21 & 2.87 \\
\hline University & 2.15 & 1.8 & 1.67 & 2.14 & 2.51 \\
\hline $\begin{array}{l}\text { Duration } \\
\% \text { Long Term }\end{array}$ & 69.69 & 83.38 & & 68.89 & 81.15 \\
\hline
\end{tabular}

Source: Based on PLFS data.

Table 2

Changes in the Sectoral Composition of Employment in Poland 1992-1998

\begin{tabular}{|c|c|c|c|c|c|c|c|}
\hline & & & & icture $(\%)$ & & & Total Change (\%) \\
\hline & 1993 & 1994 & 1995 & 1996 & 1997 & 1998 & 1992 to 1998 \\
\hline Total (in thousands) & 14761.2 & 14924.1 & 15129.1 & 15487.5 & 15875.3 & 15827.7 & 7.23 \\
\hline Agriculture. Hunting \& Forestry & 26.68 & 27.17 & 27.81 & 28.23 & 27.56 & 27.45 & 2.90 \\
\hline Mining and Quarrying & 2.70 & 2.52 & 2.36 & 2.19 & 2.00 & 1.82 & -32.70 \\
\hline Manufacturing & 20.23 & 20.58 & 20.51 & 20.40 & 19.69 & 19.23 & -4.93 \\
\hline Electricity, Gas \& Water Supply & 1.74 & 1.80 & 1.78 & 1.67 & 1.64 & 1.60 & -7.86 \\
\hline Construction & 5.97 & 5.72 & 5.47 & 5.61 & 5.81 & 5.76 & -3.41 \\
\hline Wholesale \& Retail Trade & 13.43 & 12.68 & 12.58 & 12.27 & 13.01 & 13.32 & -0.84 \\
\hline Hotels and Restaurants & 1.15 & 1.18 & 1.23 & 1.21 & 1.27 & 1.39 & 20.79 \\
\hline Transport, Storage \& Commerce & 5.58 & 5.66 & 5.54 & 5.37 & 5.30 & 5.27 & -5.47 \\
\hline Financial Intermediation & 1.50 & 1.69 & 1.77 & 1.85 & 1.98 & 2.12 & 41.37 \\
\hline Real Estate & 3.87 & 3.55 & 3.66 & 3.84 & 4.37 & 4.77 & 23.50 \\
\hline Public Admin. \& Defence & 2.28 & 2.52 & 2.52 & 2.60 & 2.65 & 2.65 & 16.04 \\
\hline Education & 5.90 & 5.99 & 5.93 & 5.89 & 5.79 & 5.83 & -1.17 \\
\hline Health and Social Work & 6.70 & 6.67 & 6.63 & 6.52 & 6.61 & 6.57 & -2.01 \\
\hline Other Service Activities & 2.28 & 2.28 & 2.21 & 2.36 & 2.34 & 2.21 & -2.88 \\
\hline
\end{tabular}

Source: Elaboration of statistics presented in "Employment in the National Economy", Table 2, Polish CSO.

Table 3

The Distribution of Individuals Across Labour Market States 1994-1998

\begin{tabular}{|c|c|c|c|}
\hline & Employment & Unemployment & Out of the Labour Force \\
\hline Nov 1994-Nov 1995 & 50.62 & 7.96 & 41.42 \\
\hline Nov 1995-Nov 1996 & 50.01 & 7.71 & 42.28 \\
\hline Nov 1996-Nov 1997 & 50.39 & 6.33 & 43.28 \\
\hline Nov 1997-Nov 1998 & 50.35 & 6.04 & 43.61 \\
\hline
\end{tabular}

Source: Based on PLFS data. 
Table 4

Aggregate Gross Labour Market Transition Probabilities for a Number of Transition Economies

\begin{tabular}{|c|c|c|c|c|c|c|c|c|c|c|c|}
\hline Country & Reference Period & $\mathrm{P}^{\text {eee35 }}$ & & $\mathrm{P}^{\mathrm{eu}}$ & $\mathrm{P}^{\mathrm{eo}}$ & $\mathrm{P}^{\mathrm{ue}}$ & $\mathrm{P}^{\mathrm{uu}}$ & $\mathrm{P}^{\mathrm{uo}}$ & $\mathrm{P}^{\mathrm{oe}}$ & $\mathrm{P}^{\mathrm{ou}}$ & $\mathrm{P}^{\mathrm{oO}}$ \\
\hline Poland (1) & 92/II - 92/III & 0.9525 & & 0.0180 & 0.0295 & 0.1754 & 0.2420 & 0.0666 & 0.0389 & 0.0391 & 0.9220 \\
\hline Poland (1) & 92/III - 92/IV & 0.9521 & & 0.0182 & 0.0297 & 0.1671 & 0.2205 & 0.0534 & 0.0216 & 0.0150 & 0.9634 \\
\hline Poland (1) & 92/IV - 93/I & 0.9618 & & 0.0198 & 0.0184 & 0.1002 & 0.1482 & 0.0480 & 0.0119 & 0.0124 & 0.9757 \\
\hline Poland (1) & $92 / 2-93 / I$ & 0.9554 & & 0.0187 & 0.0259 & 0.1476 & 0.2036 & 0.0560 & 0.0241 & 0.0222 & 0.9537 \\
\hline Poland (2) & $1992-1993$ & 0.884 & & 0.04 & 0.076 & 0.351 & 0.481 & 0.158 & 0.095 & 0.045 & 0.86 \\
\hline Poland (2) & $1993-1994$ & 0.897 & & 0.04 & 0.063 & 0.354 & 0.487 & 0.159 & 0.074 & 0.043 & 0.883 \\
\hline Poland & 1994/IV-1995/IV & $0.9149(0.8620)$ & 0.0529 & 0.0339 & 0.0512 & 0.3522 & 0.478 & 0.1698 & 0.0473 & 0.0329 & 0.9198 \\
\hline Poland & 1995/IV-1996/IV & $0.9201(0.8663)$ & 0.0518 & 0.0307 & 0.0492 & 0.337 & 0.492 & 0.171 & 0.0627 & 0.027 & 0.9103 \\
\hline Poland & 1996/IV-1997/IV & $0.9281(0.8749)$ & 0.0532 & 0.0249 & 0.047 & 0.366 & 0.433 & 0.201 & 0.0513 & 0.0244 & 0.9243 \\
\hline Poland & 1997/IV-1998/IV & $0.9356(0.8920)$ & 0.0436 & 0.0215 & 0.0429 & 0.3329 & 0.5026 & 0.1645 & 0.0427 & 0.0221 & 0.9352 \\
\hline Czech Republic & 1994/I - 1994/IV & 0.948 & & 0.02 & 0.032 & 0.507 & 0.318 & 0.176 & 0.046 & 0.018 & 0.936 \\
\hline Czech Republic & 1995/I - 1995/IV & 0.957 & & 0.015 & 0.028 & 0.471 & 0.362 & 0.167 & 0.051 & 0.011 & 0.938 \\
\hline Czech Republic & 1996/I - 1996/IV & 0.959 & & 0.013 & 0.028 & 0.435 & 0.422 & 0.142 & 0.042 & 0.01 & 0.948 \\
\hline Czech Republic & 1997/I - 1997/IV & 0.958 & & 0.019 & 0.024 & 0.429 & 0.448 & 0.124 & 0.041 & 0.016 & 0.944 \\
\hline Czech Republic & 1998/I - 1998/IV & 0.95 & & 0.023 & 0.028 & 0.366 & 0.535 & 0.099 & 0.036 & 0.022 & 0.942 \\
\hline Russia (3) & $1992-1993$ & 0.91 & & 0.032 & 0.058 & 0.52 & 0.323 & 0.157 & 0.087 & 0.014 & 0.899 \\
\hline Russia (3) & $1995-1996$ & 0.881 & & 0.056 & 0.062 & 0.395 & 0.459 & 0.145 & 0.076 & 0.034 & 0.891 \\
\hline \multicolumn{12}{|c|}{$\begin{array}{l}\text { (1) Steiner \& Kwiatkowski (1995) } \\
\text { (2) Gora \& Lehman (1995) } \\
\text { (3) Foley (1997) }\end{array}$} \\
\hline
\end{tabular}

${ }^{35}$ The figures in parenthesis refer to the estimated employment retention rates, (Pee), having taken into account the possibility of employment to employment transitions. 
Table 5

Disaggregated Polish Transition Probabilities: 1994 - 1998

\begin{tabular}{|c|c|c|c|c|c|c|c|c|c|c|c|}
\hline$\underline{\text { SEX }}$ & Reference Period & $\mathrm{P}^{\mathrm{ee}}$ & $\mathrm{P}^{\text {eee }}$ & $\mathrm{P}^{\mathrm{eu}}$ & $\mathrm{P}^{\mathrm{eo}}$ & $\mathrm{P}^{\text {ue }}$ & $\mathrm{P}^{\mathrm{uu}}$ & $\mathrm{P}^{\mathrm{uo}}$ & $\mathrm{P}^{\mathrm{oe}}$ & $\mathrm{P}^{\text {ou }}$ & $\mathrm{P}^{\mathrm{oO}}$ \\
\hline Males & 4Q1994 - 4Q1995 & 85.41 & 6.48 & 3.85 & 4.26 & 40.26 & 47.44 & 12.3 & 5.65 & 3.38 & 90.97 \\
\hline Males & 4Q1995 - 4Q1996 & 86.06 & 6.45 & 3.2 & 4.29 & 40.31 & 46.15 & 13.54 & 6.87 & 2.54 & 90.59 \\
\hline Males & 4Q1996 - 4Q1997 & 87.12 & 6.38 & 2.65 & 3.85 & 46.01 & 39.53 & 14.46 & 5.8 & 2.62 & 91.58 \\
\hline Males & 4Q1997 - 4Q1998 & 88.22 & 5.70 & 2.38 & 3.7 & 38.34 & 47.90 & 13.76 & 4.62 & 2.6 & 92.78 \\
\hline Females & 4Q1994 - 4Q1995 & 87.11 & 3.92 & 2.86 & 6.11 & 30.92 & 48.1 & 20.98 & 4.15 & 3.24 & 92.61 \\
\hline Females & 4Q1995 - 4Q1996 & 87.74 & 3.69 & 2.92 & 5.65 & 27.38 & 52.11 & 20.51 & 5.91 & 2.79 & 91.3 \\
\hline Females & 4Q1996 - 4Q1997 & 87.93 & 4.04 & 2.29 & 5.74 & 29 & 46.36 & 24.64 & 4.72 & 2.32 & 92.96 \\
\hline Females & 4Q1997 - 4Q1998 & 90.38 & 2.74 & 1.87 & 5.01 & 29.03 & 52.25 & 18.72 & 4.05 & 1.97 & 93.98 \\
\hline \multicolumn{12}{|l|}{ AGE } \\
\hline $15-24$ years & 4Q1994 - 4Q1995 & 73.31 & 12.88 & 7.52 & 6.29 & 42.98 & 42.76 & 14.26 & 6.14 & 7.53 & 86.33 \\
\hline $15-24$ years & 4Q1995 - 4Q1996 & 73.10 & 12.80 & 7.42 & 6.68 & 40.2 & 46.95 & 12.85 & 10.14 & 4.73 & 85.13 \\
\hline $15-24$ years & 4Q1996 - 4Q1997 & 73.65 & 14.16 & 6.02 & 6.17 & 43.82 & 41.09 & 15.09 & 10.28 & 5.9 & 83.82 \\
\hline $15-24$ years & 4Q1997 - 4Q1998 & 77.68 & 10.72 & 6.05 & 5.55 & 42.22 & 43.58 & 14.2 & 8.93 & 5.17 & 85.9 \\
\hline 25-34 years & 4Q1994 - 4Q1995 & 86.39 & 6.43 & 4.78 & 2.40 & 27.24 & 50.96 & 21.80 & 6.71 & 3.35 & 89.94 \\
\hline $25-34$ years & 4Q1995 - 4Q1996 & 85.16 & 6.90 & 4.44 & 3.5 & 36.75 & 46.77 & 16.48 & 17.74 & 8.71 & 73.55 \\
\hline $25-34$ years & 4Q1996 - 4Q1997 & 87.5 & 6.91 & 2.74 & 2.85 & 40 & 44.75 & 15.25 & 16.35 & 6.37 & 77.28 \\
\hline 25-34 years & 4Q1997 - 4Q1998 & 90.56 & 5.31 & 1.98 & 2.15 & 34.81 & 52.21 & 12.98 & 11.09 & 5.9 & 83.01 \\
\hline $35-45$ years & 4Q1994 - 4Q1995 & 89.34 & 4.76 & 3.24 & 2.66 & 37.29 & 49.34 & 13.37 & 15.99 & 8.59 & 75.42 \\
\hline $35-45$ years & 4Q1995 - 4Q1996 & 89.50 & 4.94 & 2.84 & 2.72 & 30.44 & 54.42 & 15.14 & 11.61 & 7.65 & 80.74 \\
\hline $35-45$ years & 4Q1996 - 4Q1997 & 91.55 & 4.20 & 2.32 & 1.93 & 32.75 & 47.91 & 19.34 & 10.39 & 6.59 & 83.02 \\
\hline $35-45$ years & 4Q1997 - 4Q1998 & 92.45 & 3.21 & 1.74 & 2.6 & 27.68 & 56.44 & 15.88 & 8.32 & 5.63 & 86.05 \\
\hline $46-54$ years & 4Q1994 - 4Q1995 & 88.99 & 3.16 & 1.61 & 6.24 & 27.24 & 50.97 & 21.79 & 6.71 & 3.35 & 89.94 \\
\hline $46-54$ years & 4Q1995 - 4Q1996 & 90.44 & 2.87 & 1.72 & 4.97 & 27.56 & 51.18 & 21.26 & 5.85 & 3.24 & 90.91 \\
\hline $46-54$ years & 4Q1996 - 4Q1997 & 89.80 & 2.75 & 1.71 & 5.74 & 22.29 & 40.13 & 37.58 & 4.99 & 1.79 & 93.22 \\
\hline $46-54$ years & 4Q1997 - 4Q1998 & 92.12 & 2.11 & 1.03 & 4.74 & 22.87 & 52.29 & 24.84 & 4.10 & 2.35 & 93.55 \\
\hline 55-65 years & 4Q1994 - 4Q1995 & 82.98 & 1.65 & 0.49 & 14.88 & 36.24 & 48.39 & 15.37 & 3.11 & 0.33 & 96.56 \\
\hline $55-65$ years & 4Q1995 - 4Q1996 & 85.90 & 1.78 & 0.68 & 11.64 & 15.39 & 39.56 & 45.05 & 2.86 & 0.39 & 96.75 \\
\hline $55-65$ years & 4Q1996 - 4Q1997 & 84.26 & 1.70 & 0.62 & 13.42 & 14.55 & 27.27 & 58.18 & 1.91 & 0.3 & 97.79 \\
\hline $55-65$ years & 4Q1997 - 4Q1998 & 85.71 & 1.86 & 0.73 & 11.7 & 18.52 & 46.3 & 35.18 & 1.78 & 0.25 & 97.97 \\
\hline
\end{tabular}


Table 6

Disaggregated Labour Market Transition Probabilities: 1994-1998

\begin{tabular}{|c|c|c|c|c|c|}
\hline SECTOR & Reference Period & $\mathrm{P}^{\mathrm{ee}}$ & $\mathrm{P}^{\mathrm{eee}}$ & $\mathrm{P}^{\mathrm{eu}}$ & $\mathrm{P}^{\mathrm{ee}}$ \\
\hline Public & 4Q1994 - 4Q1995 & 90.28 & 3.60 & 2.54 & 3.58 \\
\hline Public & 4Q1995 - 4Q1996 & 89.82 & 3.49 & 2.22 & 4.47 \\
\hline Public & 4Q1996 - 4Q1997 & 90.80 & 3.50 & 1.76 & 3.94 \\
\hline Public & 4Q1997 - 4Q1998 & 92.61 & 2.61 & 1.50 & 3.28 \\
\hline Private & 4Q1994 - 4Q1995 & 82.93 & 6.64 & 4.08 & 6.35 \\
\hline Private & 4Q1995 - 4Q1996 & 84.62 & 6.43 & 3.70 & 5.25 \\
\hline Private & 4Q1996 - 4Q1997 & 85.30 & 6.53 & 2.97 & 5.20 \\
\hline Private & 4Q1997 - 4Q1998 & 87.06 & 5.45 & 2.56 & 4.93 \\
\hline \multicolumn{6}{|l|}{ FIRM SIZE } \\
\hline Less than 5 Employees & 4Q1994 - 4Q1995 & 85.58 & 5.25 & 2.64 & 6.53 \\
\hline Less than 5 Employees & 4Q1995 - 4Q1996 & 87.07 & 5.13 & 2.71 & 5.09 \\
\hline Less than 5 Employees & 4Q1996 - 4Q1997 & 87.18 & 5.48 & 1.92 & 5.42 \\
\hline Less than 5 Employees & 4Q1997 - 4Q1998 & 89.16 & 3.98 & 1.93 & 4.93 \\
\hline 6-20 Employees & 4Q1994 - 4Q1995 & 78.38 & 8.48 & 7.73 & 5.41 \\
\hline 6-20 Employees & 4Q1995 - 4Q1996 & 80.98 & 8.25 & 5.30 & 5.47 \\
\hline 6-20 Employees & 4Q1996 - 4Q1997 & 81.57 & 9.21 & 4.61 & 4.61 \\
\hline 6-20 Employees & 4Q1997 - 4Q1998 & 84.43 & 7.32 & 3.5 & 4.75 \\
\hline 21-50 Employees & 4Q1994-4Q1995 & & & & \\
\hline 21-50 Employees & 4Q1995 - 4Q1996 & 83.05 & 7.65 & 4.96 & 4.34 \\
\hline 21-50 Employees & 4Q1996 - 4Q1997 & 85.92 & 5.08 & 4.05 & 4.95 \\
\hline 21-50 Employees & 4Q1997 - 4Q1998 & 88.25 & 4.93 & 2.77 & 4.05 \\
\hline 51-100 Employees & 4Q1994-4Q1995 & 86.50 & 5.19 & 3.49 & 4.82 \\
\hline 51-100 Employees & 4Q1995 - 4Q1996 & 86.31 & 5.46 & 3.13 & 5.10 \\
\hline 51-100 Employees & 4Q1996 - 4Q1997 & 90.69 & 3.58 & 1.46 & 4.27 \\
\hline 51-100 Employees & 4Q1997 - 4Q1998 & 90.73 & 4.12 & 2.06 & 3.09 \\
\hline More than 101 Employees & 4Q1994-4Q1995 & 91.46 & 3.09 & 1.85 & 3.60 \\
\hline More than 101 Employees & 4Q1995 - 4Q1996 & 90.84 & 3.18 & 1.71 & 4.27 \\
\hline More than 101 Employees & 4Q1996 - 4Q1997 & 90.69 & 3.58 & 1.46 & 4.27 \\
\hline More than 101 Employees & 4Q1997-4Q1998 & 92.23 & 2.89 & 1.32 & 3.56 \\
\hline \multicolumn{6}{|c|}{ EMPLOYMENT CONTRACT } \\
\hline Full-Time Employment & 4Q1994-4Q1995 & 86.31 & 5.56 & 4.20 & 3.93 \\
\hline Full-Time Employment & 4Q1995 - 4Q1996 & 86.55 & 5.65 & 3.44 & 4.36 \\
\hline Full-Time Employment & 4Q1996 - 4Q1997 & 87.77 & 5.49 & 2.8 & 3.94 \\
\hline Full-Time Employment & 4Q1997 - 4Q1998 & 88.98 & 4.84 & 2.57 & 3.61 \\
\hline Part-Time Employment & 4Q1994 - 4Q1995 & 62.52 & 11.76 & 9.02 & 16.7 \\
\hline Part-Time Employment & 4Q1995 - 4Q1996 & 65.50 & 9.17 & 9.9 & 15.43 \\
\hline Part-Time Employment & 4Q1996 - 4Q1997 & 67.11 & 11.61 & 8.48 & 12.8 \\
\hline Part-Time Employment & 4Q1997 - 4Q1998 & 75.27 & 7.94 & 5.8 & 10.99 \\
\hline
\end{tabular}


Table 7

Multinomial Estimates (Marginal Effects) of Individual Reallocation: Q4/1994 - Q4/1995*

\begin{tabular}{|c|c|c|c|c|}
\hline & $\bar{E}$ & Job to Job & $E-U$ & $E-\mathrm{OOL}$ \\
\hline \multicolumn{5}{|l|}{ Age } \\
\hline$\overline{\text { Age }} 1524$ & $-0.05(-3.75)$ & $0.17(2.38)$ & $0.0001(0.05)$ & $0.03(3.03)$ \\
\hline Age 2534 & $-0.003(-0.45)$ & $0.01(1.15)$ & $0.003(1.39)$ & $-0.005(-0.97)$ \\
\hline Age 4654 & $-0.03(-3.52)$ & $-0.01(-1.91)$ & $-0.01(-2.34)$ & $0.05(5.96)$ \\
\hline Age 5565 & $-0.15(-7.28)$ & $-0.02(-4.64)$ & $-0.01(-5.37)$ & $0.19(9.08)$ \\
\hline \multicolumn{5}{|l|}{ Education: } \\
\hline University & $0.03(2.53)$ & $0.01(0.98)$ & $-0.02(-8.38)$ & $-0.02(-3.67)$ \\
\hline Post-secondary & $0.03(2.30)$ & $-0.004(-0.39)$ & $-0.01(-1.69)$ & $-0.02(-2.83)$ \\
\hline Vocational secondary & $0.02(3.36)$ & $-0.005(-1.07)$ & $-0.01(-4.07)$ & $-0.01(-2.35)$ \\
\hline General secondary & $-0.003(-0.22)$ & $0.01(1.12)$ & $-0.01(-1.72)$ & $-0.004(-0.60)$ \\
\hline Basic vocational & $0.01(1.35)$ & $0.0003(0.06)$ & $-0.004(-2.02)$ & $-0.005(-1.19)$ \\
\hline \multicolumn{5}{|l|}{ Marital Status } \\
\hline$\overline{\text { Single women }}$ & $-0.002(-0.21)$ & $-0.01(-2.45)$ & $-0.002(-0.59)$ & $0.02(1.69)$ \\
\hline Married women & $0.01(0.50)$ & $-0.02(-4.36)$ & $-0.01(-2.25)$ & $0.02(2.79)$ \\
\hline Married men & $0.01(1.71)$ & $-0.01(-1.51)$ & $-0.003(-1.33)$ & $-0.004(-0.61)$ \\
\hline \multicolumn{5}{|l|}{ Tenure: } \\
\hline 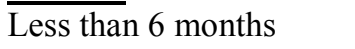 & $-0.35(-14.93)$ & $0.20(8.83)$ & $0.10(6.30)$ & $0.05(4.49)$ \\
\hline 6-12 months & $-0.18(-6.82)$ & $0.08(3.84)$ & $0.07(4.10)$ & $0.04(2.44)$ \\
\hline $1-2$ years & $-0.13(-6.46)$ & $0.08(5.02)$ & $0.03(3.27)$ & $0.02(1.62)$ \\
\hline $3-5$ years & $-0.048(-6.69)$ & $0.05(4.98)$ & $0.02(3.20)$ & $0.02(2.74)$ \\
\hline $6-10$ years & $-0.003(-2.71)$ & $0.01(1.91)$ & $0.01(1.33)$ & $0.01(1.15)$ \\
\hline \multicolumn{5}{|l|}{ Occupation: } \\
\hline Parliament/Managers & $0.04(4.43)$ & $-0.02(-3.25)$ & $-0.001(-3.40)$ & $-0.01(-2.04)$ \\
\hline Professionals & $0.04(3.55)$ & $-0.02(-2.93)$ & $-0.01(-3.01)$ & $-0.008(-1.18)$ \\
\hline Technician & $0.03(2.75)$ & $-0.01(-2.12)$ & $-0.007(-2.48)$ & $-0.006(-0.91)$ \\
\hline Clerks & $0.02(1.92)$ & $-0.01(-0.59)$ & $-0.002(-0.46)$ & $-0.01(-2.31)$ \\
\hline Personal services & $0.003(0.27)$ & $-0.003(-0.51)$ & $0.0001(0.12)$ & $0.003(0.06)$ \\
\hline Semi-skilled & $-0.001(-0.12)$ & $-0.004(-0.84)$ & $-0.001(-0.45)$ & $0.006(0.99)$ \\
\hline \multicolumn{5}{|l|}{ Firm Size: } \\
\hline$\overline{<5 \text { employees }}$ & $-0.03(-2.56)$ & $0.01(0.95)$ & $0.01(1.76)$ & $0.01(1.97)$ \\
\hline 6-20 employees & $-0.06(-4.96)$ & $0.04(3.45)$ & $0.02(3.70)$ & $0.01(1.50)$ \\
\hline 21-50 employees & $-0.05(-4.44)$ & $0.04(4.05)$ & $0.02(2.51)$ & $0.01(0.74)$ \\
\hline 51-100 employees & $-0.02(-1.79)$ & $0.02(1.62)$ & $0.01(1.26)$ & $0.002(0.27)$ \\
\hline \multicolumn{5}{|l|}{ Sector } \\
\hline$\overline{\text { Agriculture }}$ & $0.002(0.20)$ & $0.01(1.62)$ & $-0.01(-3.57)$ & $-0.01(-0.90)$ \\
\hline Industry & $-0.001(-0.13)$ & $0.01(0.69)$ & $0.0003(0.13)$ & $-0.003(-0.61)$ \\
\hline Construction & $-0.06(-3.50)$ & $0.04(3.20)$ & $0.01(1.08)$ & $0.01(1.37)$ \\
\hline Services & $-0.02(-2.08)$ & $0.01(0.88)$ & $0.002(0.75)$ & $0.01(1.84)$ \\
\hline \multicolumn{5}{|l|}{ Metropolitan Area } \\
\hline$>100.000$ inhabitants & $-0.01(-1.13)$ & $0.03(0.83)$ & $-0.003(-1.68)$ & $0.01(1.66)$ \\
\hline \multicolumn{5}{|l|}{ Regional Conditions: } \\
\hline Unemployment rate & $-0.001(-1.23)$ & $-0.001(-2.14)$ & $0.001(4.01)$ & $0.001(1.98)$ \\
\hline Vacancy rate & $-0.03(-0.99)$ & $-0.01(-0.30)$ & $0.03(2.35)$ & $0.01(0.58)$ \\
\hline N (No. of Observations) & 11,874 & & & \\
\hline Log Likelihood & -5690.0438 & & & \\
\hline
\end{tabular}

${ }^{*}$ The marginal effect equals $\mathrm{dy} / \mathrm{dx}$ for a discrete change of moving from the default categories: prime age worker (35-44 years); elementary or lower education; single male; > 10 years tenure; unskilled; public sector; >100 employees. For continual variables $(*)$ this effect is calculated at the mean value. T-statistics are reported in parenthesis. 
Table 8

Multinomial Estimates (Marginal Effects) of Individual Reallocation: Q4/1997 - Q4/1998*

\begin{tabular}{|c|c|c|c|c|}
\hline & $\bar{E}$ & Job to Job & $E-U$ & $E-\mathrm{OOL}$ \\
\hline \multicolumn{5}{|l|}{ Age } \\
\hline$\overline{\text { Age }} 1524$ & $-0.02(-3.21)$ & $0.02(2.85)$ & $0.0003(1.25)$ & $0.03(2.92)$ \\
\hline Age 2534 & $-0.01(-1.45)$ & $0.01(1.56)$ & $-0.0001(-0.42)$ & $-0.0004(-1.05)$ \\
\hline Age 4654 & $0.01(1.10)$ & $-0.01(-1.39)$ & $-0.0002(-1.52)$ & $0.002(3.11)$ \\
\hline Age 5565 & $-0.03(-0.54)$ & $-0.01(-1.06)$ & $-0.0003(-1.45)$ & $0.01(5.91)$ \\
\hline \multicolumn{5}{|l|}{ Education: } \\
\hline University & $-0.01(-0.69)$ & $0.01(0.91)$ & $-0.001(4.89)$ & $-0.001(-3.19)$ \\
\hline Post-secondary & $0.01(0.58)$ & $-0.05(-0.50)$ & $-0.0003(-0.95)$ & $-0.001(-0.67)$ \\
\hline Vocational secondary & $0.002(0.34)$ & $-0.001(-0.23)$ & $-0.0003(-2.11)$ & $-0.0002(-0.65)$ \\
\hline General secondary & $-0.001(-0.19)$ & $0.0002(0.02)$ & $-0.001(-1.33)$ & $0.001(1.25)$ \\
\hline Basic vocational & $-0.002(-0.48)$ & $0.003(0.68)$ & $-0.0002(-1.96)$ & $-0.001(-2.01)$ \\
\hline \multicolumn{5}{|l|}{ Marital Status } \\
\hline Single women & $0.01(2.97)$ & $-0.01(-3.11)$ & $0.0001(0.71)$ & $0.0001(0.29)$ \\
\hline Married women & $0.12(2.78)$ & $-0.01(-3.24)$ & $-0.0002(-1.24)$ & $0.02(2.76)$ \\
\hline Married men & $-0.003(-0.69)$ & $0.004(0.82)$ & $-0.0002(-1.28)$ & $-0.0003(-083)$ \\
\hline \multicolumn{5}{|l|}{ Tenure: } \\
\hline Less than 6 months & $-0.24(-9.78)$ & $0.23(9.32)$ & $0.005(4.41)$ & $0.004(4.18)$ \\
\hline 6-12 months & $-0.12(5.82)$ & $0.12(5.57)$ & $0.003(3.28)$ & $0.002(2.12)$ \\
\hline $1-2$ years & $-0.08(-5.42)$ & $0.08(5.16)$ & $0.003(3.64)$ & $0.001(1.10)$ \\
\hline $3-5$ years & $-0.03(-3.93)$ & $0.03(3.81)$ & $0.001(2.02)$ & $0.0003(0.68)$ \\
\hline $6-10$ years & $-0.02(-2.17)$ & $0.02(2.09)$ & $0.0003(1.02)$ & $0.0003(0.71)$ \\
\hline \multicolumn{5}{|l|}{ Occupation: } \\
\hline$\overline{\text { Parliament/Managers }}$ & $0.02(3.02)$ & $-0.01(-2.63)$ & $-0.0007(-4.75)$ & $-0.001(-4.08)$ \\
\hline Professionals & $0.01(1.68)$ & $-0.01(-1.39)$ & $-0.0006(-3.88)$ & $-0.001(-3.53)$ \\
\hline Technician & $0.01(2.05)$ & $-0.01(-1.66)$ & $-0.0006(-4.13)$ & $-0.001(-4.94)$ \\
\hline Clerks & $0.05(7.37)$ & $-0.002(-0.28)$ & $-0.01(-9.02)$ & $-0.03(-17.59)$ \\
\hline Personal services & $0.004(0.69)$ & $-0.003(-0.49)$ & $-0.0003(-1.74)$ & $-0.001(-2.48)$ \\
\hline Semi-skilled & $0.02(4.10)$ & $-0.01(-3.74)$ & $-0.002(-1.46)$ & $-0.001(-4.23)$ \\
\hline \multicolumn{5}{|l|}{ Firm Size: } \\
\hline$\overline{<5 \text { employees }}$ & $0.0020 .37)$ & $-0.001(-0.36)$ & $0.0002(1.20)$ & $-0.0003(-0.67)$ \\
\hline 6-20 employees & $-0.01(-2.62)$ & $0.01(2.53)$ & $0.0004(1.85)$ & $0.0002(0.56)$ \\
\hline 21-50 employees & $-0.01(-1.60)$ & $0.01(1.55)$ & $0.0003(1.30)$ & $0.0001(0.17)$ \\
\hline 51-100 employees & $-0.02(-1.39)$ & $0.01(1.41)$ & $0.0003(0.96)$ & $-0.0003(-0.75)$ \\
\hline \multicolumn{5}{|l|}{ Sector } \\
\hline$\overline{\text { Agriculture }}$ & $-0.01(-1.48)$ & $0.01(1.44)$ & $-0.0004(-1.53)$ & $0.001(1.11)$ \\
\hline Industry & $-0.01(-1.61)$ & $0.01(1.38)$ & $0.0003(1.28)$ & $0.001(2.02)$ \\
\hline Construction & $-0.03(-2.99)$ & $0.03(2.79)$ & $0.0005(1.36)$ & $0.002(2.02)$ \\
\hline Services & $-0.01(-1.85)$ & $0.01(1.68)$ & $0.0003(1.51)$ & $0.001(1.38)$ \\
\hline \multicolumn{5}{|l|}{ Metropolitan Area } \\
\hline$>100.000$ inhabitants & $-0.003(-0.85)$ & $0.003(0.99)$ & $-0.00004(-0.03)$ & $-0.001(-1.57)$ \\
\hline \multicolumn{5}{|l|}{ Regional Conditions: } \\
\hline Unemployment rate & $0.0004(0.35)$ & $-0.0002(-0.46)$ & $0.00003(2.16)$ & $0.00001(0.29)$ \\
\hline Vacancy rate & $0.002(1.42)$ & $-0.0003(-1.33)$ & $-0.0002(-1.67)$ & $-0.0001(-0.49)$ \\
\hline N (No. of Observations) & 12,152 & & & \\
\hline Log Likelihood & -4916.0495 & & & \\
\hline
\end{tabular}

* The marginal effect equals $\mathrm{dy} / \mathrm{dx}$ for a discrete change of moving from the default categories: prime age worker (35-44 years); elementary or lower education; single male; $>10$ years tenure; unskilled; public sector; $>100$ employees. For continual variables $(*)$ this effect is calculated at the mean value. T-statistics are reported in parenthesis. 
Table 9

Multinomial Estimates (Marginal Effects) of Individual Reallocation*

\begin{tabular}{|c|c|c|c|c|c|c|}
\hline \multirow[b]{2}{*}{ Age } & \multicolumn{2}{|c|}{ UE } & \multicolumn{2}{|c|}{$\mathrm{U}$} & \multicolumn{2}{|c|}{$\mathrm{U}-\mathrm{OOL}$} \\
\hline & 1994 & 1998 & 1994 & 1998 & 1994 & 1998 \\
\hline$\overline{\text { Age }} 1524$ & $0.04(0.86)$ & $0.15(3.41)$ & $-0.07(-1.59)$ & $-0.13(-2.99)$ & $0.34(1.01)$ & $-0.02(-0.56)$ \\
\hline Age 2534 & $-0.003(-0.12)$ & $0.05(1.45)$ & $0.02(0.74)$ & $-0.03(-0.80)$ & $-0.02(0.88)$ & $-0.02(-0.95)$ \\
\hline Age 4654 & $-0.08(-2.33)$ & $-0.06(-1.24)$ & $-0.3(-0.68)$ & $-0.03(-0.54)$ & $0.11(2.96)$ & $0.09(2.01)$ \\
\hline Age 5565 & $-0.17(-3.33)$ & $-0.11(-1.40)$ & $-0.12(-1.49)$ & $-0.06(-0.75)$ & $0.29(3.62)$ & $0.17(2.09)$ \\
\hline \multicolumn{7}{|l|}{ Education: } \\
\hline University & $0.21(2.07)$ & $0.41(4.02)$ & $-0.08(-0.83)$ & $-0.33(-3.66)$ & $-0.13(-6.97)$ & $-0.08(-1.77)$ \\
\hline Post-secondary & $0.05(0.60)$ & $0.34(4.05)$ & $-0.02(-0.26)$ & $-0.30(-4.40)$ & $-0.03(-0.52)$ & $-0.04(-0.72)$ \\
\hline Vocational secondary & $0.11(2.80)$ & $0.24(5.08)$ & $-0.10(-2.54)$ & $-0.22(-5.30)$ & $.0 .01(-0.43)$ & $-0.01(-0.47)$ \\
\hline General secondary & $0.15(2.50)$ & $0.17(2.72)$ & $-0.15(-2.67)$ & $-0.20(-3.76)$ & $-0.002(-0.06)$ & $0.03(0.62)$ \\
\hline Basic vocational & $0.07(2.36)$ & $0.13(3.58)$ & $-0.4(-1.34)$ & $-0.13(-3.61)$ & $-0.03(-1.31)$ & $-0.0004(-0.02)$ \\
\hline \multicolumn{7}{|l|}{ Marital Status } \\
\hline$\overline{\text { Single women }}$ & $-0.04(-1.16)$ & $-0.03(-0.87)$ & $-0.42(-1.03)$ & $0.03(0.57)$ & $0.08(2.16)$ & $0.01(0.25)$ \\
\hline Married women & $-0.03(-0.99)$ & $-0.09(-2.53)$ & $-0.09(-2.37)$ & $0.02(0.58)$ & $0.13(3.60)$ & $0.07(2.14)$ \\
\hline Married men & $0.08(2.26)$ & $0.09(2.05)$ & $-0.12(-2.96)$ & $-0.11(-2.36)$ & $0.30(0.87)$ & $0.02(0.45)$ \\
\hline \multicolumn{7}{|l|}{ Job Search Duration: } \\
\hline$\overline{\text { Less than } 3 \text { months }}$ & $0.21(3.55)$ & $0.11(1.31)$ & $-0.18(-3.45)$ & $-0.16(-2.15)$ & $-0.03(-0.94)$ & $0.05(0.85)$ \\
\hline 3- 6 months & $0.26(4.39)$ & $0.09(1.07)$ & $-0.24(-4.63)$ & $-0.15(-1.93)$ & $-0.02(-0.71)$ & $0.06(0.90)$ \\
\hline $6-12$ months & $0.20(3.43)$ & $0.07(0.84)$ & $-0.19(-3.84)$ & $-0.06(-0.75)$ & $-0.01(-0.15)$ & $-0.01(-0.15)$ \\
\hline $1-3$ years & $0.12(2.34)$ & $0.03(0.44)$ & $-0.09(-1.83)$ & $-0.02(-0.33)$ & $-0.03(-1.09)$ & $0.06(0.91)$ \\
\hline \multicolumn{7}{|l|}{ Previous Occupation: } \\
\hline Parliament/Managers & $-0.10(-1.24)$ & $-0.02(-0.24)$ & $0.07(0.65)$ & $0.01(0.07)$ & $0.03(0.36)$ & $0.02(0.24)$ \\
\hline Professionals & $0.11(1.15)$ & $-0.01(-0.09)$ & $-0.17(-1.87)$ & $-0.01(-0.04)$ & $0.06(0.78)$ & $0.02(0.18)$ \\
\hline Technician & $0.01(0.09)$ & $-0.11(-2.13)$ & $0.04(0.64)$ & $0.06(0.97)$ & $-0.04(-1.24)$ & $0.05(0.94)$ \\
\hline Clerks & $-0.07(-1.35)$ & $-0.05(-0.91)$ & $0.02(0.29)$ & $0.03(0.40)$ & $0.05(1.13)$ & $0.03(0.57)$ \\
\hline Personal services & $-0.05(-1.30)$ & $0.05(0.82)$ & $-0.004(-0.08)$ & $-0.07(-1.33)$ & $0.06(1.56)$ & $0.03(0.67)$ \\
\hline Semi-skilled & $0.001(0.03)$ & $0.01(0.30)$ & $0.01(0.29)$ & $0.02(0.36)$ & $-0.01(-0.41)$ & $-0.03(-0.99)$ \\
\hline Previous WorkExperience & $0.12(2.27)$ & $0.03(0.79)$ & $0.32(3.36)$ & $0.02(0.33)$ & $0.002(0.06)$ & $0.32(0.76)$ \\
\hline Registered at E Office & $0.05(1.42)$ & $0.05(1.55)$ & $0.06(1.61)$ & $-0.04(-1.06)$ & $-0.10(-3.56)$ & $-0.01(-0.49)$ \\
\hline Receiving U Benefit & $0.07(2.45)$ & $0.10(2.48)$ & $-0.06(-1.80)$ & $-0.04(-1.04)$ & $-0.01(-0.58)$ & $-0.05(-2.17)$ \\
\hline Seeking Part-time Work & $-0.18(-5.31)$ & $-0.08(-1.76)$ & $0.12(2.72)$ & $-0.03(-0.64)$ & $0.06(1.91)$ & $0.11(2.62)$ \\
\hline \multicolumn{7}{|l|}{$\underline{\text { Sector }}$} \\
\hline$\overline{\text { Agriculture }}$ & $0.11(1.75)$ & $-0.34(-0.50)$ & $-0.11(-1.97)$ & $0.03(0.41)$ & $0.01(0.23)$ & $0.004(0.10)$ \\
\hline Industry & $0.12(2.79)$ & $0.04(0.71)$ & $-0.08(-1.89)$ & $-0.02(-0.41)$ & $-0.04(-1.52)$ & $-0.02(-0.45)$ \\
\hline Construction & $0.14(2.68)$ & $0.07(1.05)$ & $-0.12(-2.28)$ & $-0.04(-0.57)$ & $-0.03(-0.82)$ & $-0.03(-0.78)$ \\
\hline Services & $0.11(2.60)$ & $0.01(0.30)$ & $-0.08(-1.89)$ & $0.03(0.56)$ & $-0.03(-1.30)$ & $-0.04(-1.42)$ \\
\hline Unknown & $-0.34(27.42)$ & $-0.04(-0.79)$ & $-0.13(-2.35)$ & $-0.02(-0.30)$ & $0.002(0.06)$ & $0.02(0.56)$ \\
\hline \multicolumn{7}{|l|}{ Metropolitan Area } \\
\hline$\overline{\text { City }>100.000 \text { inhabitants }}$ & $0.01(0.41)$ & $0.04(1.08)$ & $-0.08(-2.59)$ & $-0.01(-0.37)$ & $0.07(2.89)$ & $-0.02(-1.08)$ \\
\hline \multicolumn{7}{|l|}{ Regional Conditions: } \\
\hline Unemployment rate* & $-0.01(-1.92)$ & $-0.01(-2.52)$ & $0.005(1.57)$ & $0.01(3.01)$ & $0.001(0.25)$ & $0.02(1.35)$ \\
\hline \multirow[t]{2}{*}{ Vacancy rate* } & $-0.11(-0.73)$ & $0.01(0.35)$ & $0.19(1.17)$ & $-0.03(-1.23)$ & $-0.08(-0.75)$ & $-0.002(-1.35)$ \\
\hline & 1994 & 1998 & & & & \\
\hline N (No. of Observations) & 1989 & 1550 & & & & \\
\hline Log Likelihood & -1831.4397 & -1423.0142 & & & & \\
\hline
\end{tabular}

*The marginal effect equals $\mathrm{dy} / \mathrm{dx}$ for a discrete change of moving from the default categories: prime age individual (35-44 years); elementary or lower education; single male; $>3$ years job search; unskilled; previously employed in the public sector; in a firm with $>100$ employees. For continual variables $(*)$ this effect is calculated at the mean value. T-statistics are reported in parenthesis. 
Table 10

Multinomial Estimates (Marginal Effects) of Individual Reallocation*

\begin{tabular}{|c|c|c|c|c|c|c|}
\hline \multirow[b]{2}{*}{ Age } & \multicolumn{2}{|c|}{$\mathrm{OOL}-\mathrm{E}$} & \multicolumn{2}{|c|}{$\mathrm{OOL}-\mathrm{U}$} & \multicolumn{2}{|c|}{ OOL } \\
\hline & 1994 & 1998 & 1994 & 1998 & 1994 & 1998 \\
\hline Age 1524 & $0.03(2.24)$ & $0.07(6.64)$ & $0.01(1.17)$ & $0.02(4.38)$ & $-0.04(-2.51)$ & $-0.09(-7.89)$ \\
\hline Age 2534 & $0.03(2.04)$ & $0.03(2.48)$ & $0.02(2.20)$ & $0.01(1.53)$ & $-0.05(-2.96)$ & $-0.04(-2.90)$ \\
\hline Age 4654 & $-0.02(-3.18)$ & $-0.02(-3.67)$ & $-0.01(-3.61)$ & $-0.01(-3.52)$ & $0.04(4.52)$ & $0.03(4.82)$ \\
\hline Age 5565 & $-0.06(-8.48)$ & $-0.05(-8.64)$ & $-0.05(-10.03)$ & $0.04(-10.81)$ & $0.11(12.90)$ & $0.08(13.13)$ \\
\hline \multicolumn{7}{|l|}{ Education: } \\
\hline University & $0.08(2.64)$ & $0.06(2.11)$ & $-0.02(-2.38)$ & $0.01(1.09)$ & $-0.07(-2.04)$ & $-0.07(-2.38)$ \\
\hline Post-secondary & $0.13(2.71)$ & $0.06(2.05)$ & $0.001(0.10)$ & $0.01(0.91)$ & $-0.13(-2.67)$ & $-0.07(-2.27)$ \\
\hline Vocational secondary & $0.04(2.92)$ & $0.04(3.68)$ & $0.01(1.74)$ & $0.005(1.14)$ & $-0.05(-3.44)$ & $-0.04(-3.85)$ \\
\hline General secondary & $0.07(4.33)$ & $0.02(2.36)$ & $0.001(0.21)$ & $-0.003(-0.80)$ & $-0.07(-4.22)$ & $-0.02(-1.92)$ \\
\hline Basic vocational & $0.02(2.36)$ & $0.02(2.55)$ & $0.01(1.94)$ & $0.004(1.01)$ & $-0.04(-3.07)$ & $-0.02(-2.76)$ \\
\hline \multicolumn{7}{|l|}{ Marital Status } \\
\hline$\overline{\text { Single women }}$ & $-0.01(-2.25)$ & $-0.01(-1.12)$ & $-0.0004(-0.01$ & $-0.003(-1.30)$ & $0.01(2.02)$ & $0.01(1.57)$ \\
\hline Married women & $-0.01(-1.38)$ & $-0.01(-0.99)$ & $-0.01(-1.44)$ & $-0.01(-2.26)$ & $0.02(1.87)$ & $0.01(1.83)$ \\
\hline Married men & $0.02(1.80)$ & $0.01(1.39)$ & $-0.005(-0.83)$ & $0.003(0.64)$ & $-0.02(-1.31)$ & $-0.02(-1.53)$ \\
\hline $\begin{array}{l}\text { Previous Work } \\
\text { Experience }\end{array}$ & $0.04(3.15)$ & $0.04(5.44)$ & $0.0004(0.09)$ & $0.02(4.18)$ & $-0.04(-2.95)$ & $-0.06(-6.76)$ \\
\hline \multicolumn{7}{|l|}{ Metropolitan Area } \\
\hline $\begin{array}{l}\text { City }>100.000 \\
\text { inhabitants }\end{array}$ & $-0.02(-3.12)$ & $-0.01(-1.75)$ & $-0.002(-0.63)$ & $-0.01(-0.36)$ & $0.02(3.02)$ & $-0.01(-1.15)$ \\
\hline \multicolumn{7}{|l|}{ Regional Conditions: } \\
\hline Unemployment rate* & $0.000003(0.05)$ & 5) $.001(2.37)$ & $0.001(2.73)-$ & $0.00002(-0.01)$ & $-0.001(-1.36)$ & $-0.001(-2.06)$ \\
\hline \multirow[t]{2}{*}{ Vacancy rate * } & $-0.07(-2.15)$ & $0.003(0.87)$ & $0.02(0.84)$ & $-0.03(-1.74)$ & $0.06(1.55)$ & $-0.0001(-0.02)$ \\
\hline & 1994 & 1998 & & & & \\
\hline $\mathrm{N}$ (No. of Observations) & 7352 & 8145 & & & & \\
\hline Log Likelihood & -2827.7585 & -2581.5633 & & & & \\
\hline
\end{tabular}

${ }^{*}$ The marginal effect equals $\mathrm{dy} / \mathrm{dx}$ for a discrete change of moving from the default categories: prime age individual (35-44 years); elementary or lower education; single male; no previous work experience. For continual variables (denoted by *) this effect is calculated at the mean value. T-statistics are reported in parenthesis. 